\title{
Understanding factors influencing adverse sex ratios at birth in Bangladesh
}

Md. Noorunnabi Talukder

Population Council

Ubaidur Rob

Population Council

Md. Irfan Hossain

Population Council

Forhana Rahman Noor

Population Council

Follow this and additional works at: https://knowledgecommons.popcouncil.org/departments_sbsr-pgy

Part of the Demography, Population, and Ecology Commons, Family, Life Course, and Society

Commons, Gender and Sexuality Commons, International Public Health Commons, Medicine and Health Commons, and the Women's Health Commons

How does access to this work benefit you? Let us know!

\section{Recommended Citation}

Talukder, Md. Noorunnabi, Ubaidur Rob, Md. Irfan Hossain, and Forhana Rahman Noor. 2015.

"Understanding factors influencing adverse sex ratios at birth in Bangladesh." Dhaka: Population Council. 


\section{UNDERSTANDING FACTORS}

INFLUENCING ADVERSE SEX RATIOS AT BIRTH IN BANGLADESH

MD. NOORUNNABI TALUKDER UBAIDUR ROB MD. IRFAN HOSSAIN FORHANA RAHMAN NOOR 


\title{
UNDERSTANDING FACTORS INFLUENCING ADVERSE SEX RATIOS AT BIRTH IN BANGLADESH
}

\author{
MD. NOORUNNABI TALUKDER
}

UBAIDUR ROB

MD. IRFAN HOSSAIN

FORHANA RAHMAN NOOR 


\section{POPULATION 7 COUNCIL \\ Ideas. Evidence. Impact.}

The Population Council confronts critical health and development issues-from stopping the spread of HIV to improving reproductive health and ensuring that young people lead full and productive lives. Through biomedical, social science, and public health research in 50 countries, we work with our partners to deliver solutions that lead to more effective policies, programs, and technologies that improve lives around the world. Established in 1952 and headquartered in New York, the Council is a nongovernmental, nonprofit organization governed by an international board of trustees.

Population Council

Bangladesh Country Office

House 15B, Road 13, Gulshan 1

Dhaka 1212, Bangladesh

Email: info.bangladesh@popcouncil.org

popcouncil.org

Suggested citation: Talukder, M.N., U. Rob, M.I. Hossain, F.R. Noor. 2015. "Understanding factors influencing adverse sex ratios at birth in Bangladesh." Dhaka: Population Council.

(C)2015 The Population Council, Inc. 


\section{CONTENTS}

Summary iv

List of Tables viii

List of Figures viii

Acknowledgements $\quad$ ix

I INTRODUCTION 1

II METHODOLOGY

III SEX RATIOS, GENDER PREFERENCE, AND SEX SELECTION 10

$\begin{array}{ll}\text { A. Women's profile } & 10\end{array}$

$\begin{array}{ll}\text { B. Factors underlying regional differences in sex ratios } & 13\end{array}$

- Demography of son preference 14

$\begin{array}{ll}\text { - Perception of son preference } & 21\end{array}$

- Attitudes to sex selection 28

- Fertility stopping behavior $\quad 29$

IV INITIATIVES TO ENHANCE THE STATUS OF FEMALES

A. Impact of gender-focused programs 34

$\begin{array}{ll}\text { B. Impact of advocacy and community mobilization } & 37\end{array}$

C. Legal initiatives to reduce sex selection and disclosure of fetal sex 38

V DISCUSSIONS AND RECOMMENDATIONS $\quad 42$

$\begin{array}{lr}\text { References } & 47\end{array}$ 


\section{SUMMARY}

Nationally, the sex ratio at birth (SRB) has persisted at its natural level of 105 male per 100 female newborns for the past half century in Bangladesh (UN 2013). However, at the regional level, Bangladesh is characterised by an east-west divide in sex ratios at birth. While the western region shows normal sex ratios at birth, the eastern region displays distorted sex ratios. To understand the factors that contribute to regional variations in the sex ratio at birth, a household survey was conducted among married women aged 18-49 years who had at least two living children, the youngest of whom was aged 0-5. Views of healthcare providers on gender-biased sex selection and of program implementers on the impact of gender-focused programs on the importance of having a daughter in the family were also gathered. The study was located in Comilla district from the eastern region which had an adverse sex ratio at birth and Rangpur district from the western region having a normal sex ratio.

Caution should be exercised in interpreting the findings from this study, as the size of the sample of women interviewed (1,037 respondents) was not adequate to reach a definitive conclusion. Future studies are needed that work with a larger sample, so that findings on differentials across characteristics can be generalized.

\section{Factors affecting sex ratios at birth}

Findings have highlighted that the preconditions for skewing of sex ratios prevail: the small-family norm is widespread, gender norms continue to be hierarchical and son preference exists, particularly in rural areas; and pre-natal diagnostic techniques are used by large proportions of women to both assess the development of the fetus and know the sex of the fetus. The extent to which low fertility, access to sex-selection technology and preference for sons have affected differences in the sex ratio at birth in these two contrasting districts of Bangladesh is discussed below.

\section{LOW FERTILITY AND STOPPING BEHAVIOR}

Women in both study districts exhibited a strong culture of low fertility, that is, a strong preference for a two-child family. Women in both districts had on average 2.5-2.7 living children. Women in Rangpur were more likely than those in Comilla to have just two children (66\% versus 55\%); in contrast, they were less likely than those from Comilla to have three children (23\% versus 34\%). High-parity women and their husbands do not seem to be content to have only sons or only daughters, and a strong preference for children of both sexes is evident. The distribution of women mentioning two-child ideal shows a strong desire for one boy and one girl in both study sites-women from Rangpur almost unanimously expressed the preference for one boy and one girl while such preference is slightly lower in Comilla ( $97 \%$ and $89 \%$ respectively).

Even so, son preference was evident in both districts, which is stronger in Comilla than Rangpur. The intention to have additional children was, for example, related to the sex of living children among women in Comilla. Indeed, there was some suggestion that women from Comilla with more sons than daughters were more likely than those from Rangpur to report wanting no more children (50\% and 32\% respectively). This indicates the presence of son preference in Comilla despite the desire for a small family growing stronger. Correspondingly, women from Comilla with more daughters than sons were less likely than those in Rangpur to report wanting no more children (Comilla 32\%, Rangpur: 47\%), suggestive of lack of contentment with the current composition of children. Furthermore, in Comilla, the desire for gender-balance in the number of children was stronger when couples have only daughters. For example, preference for a son as the third child is almost universal 
among women and their husbands who had two girls (90-99\%) while a less intense preference for daughters as the third child was expressed by women and their husbands who had two boys (7692\%).

Women in Comilla were more likely to report disclosure of the sex of the fetus than were those in Rangpur, and the disclosure of the sex of the fetus appeared to be contingent on the sex of the previous child. In Comilla, women at parity 2 whose first child was a daughter were more likely to have been informed about the sex of the second than were those women whose first child was a son. Associations were modest in Rangpur.

Findings suggest an increase in the use of contraception with parity, from a low use of contraception before first birth (23-29\%) to markedly higher use of contraception in second (72-79\%) and following births. Use of contraception to stop childbearing in second and higher-order births is notably higher in Comilla which implies that women from Comilla have stronger intention to avoid pregnancy at higher-order births.

Clearly, women's use of contraception was associated with the sex composition of their living children ${ }^{1}$. In Comilla, those with two sons were 50 percent more likely to have been practicing contraception than those with two daughters, while in Rangpur they were 17 percent more likely to have done so. Differences were particularly pronounced in rural areas (Comilla: 1.50, Rangpur: 1.04). These findings suggest women from Comilla were more likely to base their childbearing strategies on the number of sons they had than were those from Rangpur.

\section{DISCLOSURE OF FETAL SEX AND SEX SELECTION}

Disclosure of the sex of the fetus was widespread in Bangladesh as it is not legally restricted. The practice of knowing the fetal sex is higher among women in Comilla in which sex ratios were distorted than in Rangpur having normal sex ratio (65\% vs. $51 \%)$ and lower among rural women than among urban women. Despite large proportions of women considering disclosure of the sex of the fetus acceptable, hardly any women favored the termination of a female fetus (less than $2 \%$ ). The practice of sex-selective abortion was almost entirely absent in both study districts. Findings highlight that termination of pregnancies carrying a female fetus was almost entirely absent as revealed from both the household survey and discussions with key informants. Indeed, the study found only one case of gender-biased sex selection in its survey of 1,037 women. Instead of sex selection, women undergo pregnancy termination as a means of fertility control offered as a part of family planning services. While 8 percent of women reported pregnancy termination, almost all these pregnancy terminations took place in the first trimester of gestation, when detection of the sex of the fetus is not possible through ultrasonography, and nearly all abortion-seekers terminated pregnancies for fertility-limiting reasons.

This study suggests no discernible differences between women in the two districts in terms of sexselective abortion (which is nearly absent in both districts); however, there is a suggestion that women in Comilla were more likely than those in Rangpur to continue childbearing till they had a son, and less likely to stop childbearing at low parities, irrespective of the composition of their children. In Rangpur, a normal sex ratio coexisted with higher rates of pregnancy termination as a means of ensuring small family size, and without seeking disclosure of the sex of the fetus, as part of family building strategy.

1 The extent to which women's use of contraception was associated with the sex composition of their living children is used as an indirect way of measuring the influence of son preference on the family planning behavior of couples. A simple indicator was constructed which measures the ratio of the proportion of women with two sons currently using contraception with the proportion of women with two daughters using contraception. 


\section{PERCEPTION ON SON PREFERENCE}

Perception of sex preference among women indicates an increase in preferences for both son and daughter with increasing birth order, as women continue to have children until they achieve their desired composition of children. Demographic preference of son by parity indicates no notable difference across districts while it was stronger in rural than in urban setting.

Encouragingly, Rangpur, the district with normal sex ratio, exhibited a culture of attaching greater value on girls. Women in Rangpur were considerably more likely than those in Comilla to believe that a daughter can support her parents in their old age and a girl should inherit same amount of property as a boy, suggestive of a culture of greater autonomy for girls and women in Rangpur than in Comilla. It is worth noting that this district is credited for large contribution of female labor force to apparel industry and small industries, and greater financial reliance of parents on working daughters.

Surprisingly, attitudes reflecting son preference were more pronounced among rural women from Rangpur, which is not consistent with its lower sex ratio at birth. It is perhaps the lower education level and poor economic condition of rural Rangpur that are assumed to lead women to express more intense preference for son.

\section{Gender-focused initiatives to improve status of females}

\section{EXPOSURE TO FINANCIAL OPPORTUNITIES}

Female secondary-school stipend program. Conditional cash transfer programs for secondary school girls are implemented in Bangladesh. Use of school stipend program is higher in Rangpur than in Comilla. Views of program implementers (both national and district) regarding the impact of female school stipend program on improving the situation of girls were mixed. For example, the stipend program was observed to have played some role in delaying age at marriage for girls, conforming to one of the key conditions for receiving cash stipend. Only a few implementers considered the program useful in changing attitudes about girls; and not a single program implementer believed that the stipend program has brought changes in the demand for son/daughter.

Micro-credit program. Microfinance provides self-employment to millions of female entrepreneurs in Bangladesh. Impact of micro-credit in reducing discrimination against women was strongly perceived by the majority of women. Similarly, program implementers mentioned a relationship between microcredit and increased importance of daughter in the family.

Employment in apparel industry. Apparel industry appears to have increased importance of daughter in the family. Daughters are valued more than previously among poor families as female garmentworkers provide some income support for their parents.

\section{EXPOSURE TO ADVOCACY AND COMMUNITY MOBILIZATION}

Findings suggest that programs relating specifically to promoting awareness of gender-biased sex selection (or termination of pregnancies carrying a female fetus) do not exist in the country. Exposure to advocacy and community mobilization programs related, rather, to non-discrimination against daughters occurred in both Rangpur and Comilla. More women from Comilla than Rangpur were likely to be exposed to messages about equal treatment of daughters and sons delivered by religious leaders and healthcare providers. The extent of NGO advocacy activities was clearly limited in the study districts. 


\section{LEGAL INITIATIVES}

Lack of awareness on the abortion law among women was universal in study sites. There is no law in the country that prohibits gender-biased sex selection. Findings suggest that women did not typically perceive a need for a law to prevent gender-biased sex selection; even so, more women in Comilla than Rangpur perceived this need (39\% versus 13\%).

Abortion is often performed violating the law of gestation (beyond 10 weeks) and abortion laws were inadequately enforced. Key informants from both study districts suggested that abortions beyond ten weeks of gestation did take place, and that there was no system whereby abortions were monitored at the district level. Whether the law was enforced after illegal abortion had taken place is not known to most key informants. Perceptions of key informants concurred with reports of women that sexselective abortions are extremely rare. Key informants also noted that there have been no programs in place to raise awareness about gender-biased sex selection among service providers.

\section{Way forward}

Women in both study districts exhibited a strong preference for a two-child family. The practice of disclosing the sex of the fetus is widespread in both study districts but the practice of sex-selective abortion was almost entirely absent, and women strongly opposed gender-biased pregnancy termination. Despite these similarities, findings suggest a stronger desire for a male child in Comilla than Rangpur. In Comilla, the sex of living children had an effect on the desire of women for more children and the use of contraception. Overall, the findings are inconclusive and mixed. There is a need for further research covering several other pockets that have distorted sex ratios at birth.

Several recommendations emerge from this study that have relevance for efforts to ensure a balanced sex ratio at birth. Indeed, given that gender-biased sex selection is not a serious concern at present, measures are needed that challenge gender norms and strongly held preferences for sons over daughters:

- Expand programs intended to enhance the autonomy of women and girls: It is critical to enhance the autonomy of women and girls, by increasing opportunities for subsidized education for girls and for paid employment for women; our findings have suggested that perceptions about the value of girls can change when communities observe girls providing economic support to parents substituting economic role of sons.

- Provide safety nets to protect poor rural women: At the same time, safety net programs for poor rural women can be a useful instrument for reducing son preference, since poverty remains a key driver for son preference in the rural setting. Such programs will not only provide much-needed support to poor women in the short term, but may also change attitudes about reliance of sons for old-age support in the longer term.

- Guideline needed to prohibit the use of technology for sex detection. Potential exists for misuse of disclosure of the sex of the fetus; therefore, a clearly defined service protocol on using the technology for sex detection is needed.

- Strengthen advocacy and community mobilization efforts intended to challenge gender norms: It is essential that outreach and other programs are implemented that attempt to break down traditional norms about sons versus daughters, while at the same time focusing on parents to promote equal opportunities for daughters and sons, and enhance awareness about and encourage parents to access available programs and entitlements for their daughters. 


\section{LIST OF TABLES}

Table 1: Coverage of the household survey

Table 2: Coverage of the key informant interviews

Table 3: Selected background characteristics of women by sites

Table 4: Perception about gender role among married women of reproductive age (in percent)

Table 5: Female autonomy in mobility and financial empowerment (in percent)

Table 6: Ideal number of children among women by sites (in percent)

Table 7: Distribution of women by their actual family size (in percent)

Table 8: Number and composition of living children among women who want no more children (in percent)

Table 9: Future fertility intention among women

Table 10: Indicators of son preference among women who have two living children

Table 11: Women reporting various attitudes relating to son preference (in percent)

Table 12: Women reporting attitudes reflecting girl value (in percent)

Table 13: Attitude towards sex selection among women (in percent)

Table 14: Use of contraception among women by order of births (in percent)

Table 15: Use of ultrasound to obtain information about sex of the fetus (in percent)

Table 16: Use of ultrasound to know sex of the fetus by relatives and other women in community (in percent)

Table 17: Percentages of women by experiences of personal disclosure of the sex of the fetus by parity and sex of previous child

Table 18: Pregnancy termination and its reasons women (in percent)

Table 19: Exposure to CCT and microcredit program (in percent)

Table 20: Exposure to advocacy and community mobilization (in percent)

Table 21: Perception among women on the necessity of law for prohibiting sex selection (in percent)

\section{LIST OF FIGURES}

Figure 1: Perceived gender preference among women by fertility ideals (in percent)

Figure 2: Gender preference among women, husband and mother-in-law for the second birth (in percent)

Figure 3: Gender preference among women, husband and mother-in-law for the third birth (in percent) 


\section{ACKNOWLEDGEMENTS}

We are grateful to the UK Department for International Development (UKaid) for providing the funding for this research project, and to Nupur Barua, Deputy Head, South Asia Research Hub at Department for International Development (DFID), British High Commission, New Delhi for her technical assistance and support during the process.

We benefited immensely from the comments of Nupur Barua, Deputy Head, South Asia Research Hub at DFID, New Delhi on the draft of the report. We would like to express our deep appreciation to Shireen Jejeebhoy, Senior Associate, Population Council for her comments on the report. We are thankful to Mohammad Bellal Hossain, Associate Professor, Department of Population Sciences, University of Dhaka, Bangladesh for reviewing the draft of the report.

We are grateful to Mohammed Sharif, Director, Maternal and Child Health Services and Line Director, Maternal Child-Reproductive Health, Directorate General of Family Planning (DGFP), Ministry of Health and Family Welfare (MOHFW) for his support that facilitated cooperation of the field-level functionaries in data collection.

The participants are the key to the study; we sincerely thank the women who participated at the household survey from Daudkandi Upazilla in Comilla and Gangachara Upazilla in Rangpur. We would like to express our deep appreciation to the program implementers and healthcare providers who participated in key informant interviews and provided valuable insights.

We would like to acknowledge the contribution of 12 investigators who conducted interviews on a new and challenging topic with women, program implementers and healthcare providers.

Finally, we are grateful to Population Council colleagues for technical, administrative and logistical support. Particularly, we appreciate the efforts of Afsana Fatema Noor for transcribing the qualitative data and sorting them by themes. 


\section{INTRODUCTION}

The Population Council, with support from the UKAid, has undertaken a study to shed light on the issue of gender-biased sex selection and to make evidence-based recommendations for actions that hold promise for responding to adverse sex ratios at birth. This was a four-country project involving Bangladesh, India, Pakistan and Nepal. The project was implemented under the leadership of the Population Council's India office, with Country offices being responsible for implementing respective country-specific studies.

The project was designed to be implemented in two phases. In the first phase, researchers reviewed and synthesized the available evidence on the sex ratio at birth (SRB) and on the available programs to raise the value of girls and women, and identified key research topics for the second phase. The second phase contained primary research in which researchers explored key emerging questions: the factors behind the regional variation in the sex ratio at birth in the country, particularly factors affecting the unbalanced sex ratio at birth. This report presents findings from the second phase of the sex selection study in Bangladesh.

The first phase of the project examined the situation and dynamics of the sex ratio at birth in Bangladesh, using a mix of literature review and analysis of Demographic and Health Survey (DHS) data. In addition, it examined the initiatives towards gender equality that have contributed to closing the gender gap in social and economic opportunities and raising the value of girls and women. Findings from the first phase suggest a normal sex ratio at birth ${ }^{2}$ in Bangladesh with wide regional variations and a growing indifference to the sex of a child.

Bangladesh is administratively divided into 7 divisions and 64 districts. Twenty-six districts in 3 divisions constitute the western region, 15 districts in 2 divisions lie in the eastern region while the middle region includes 23 districts in 2 divisions. Regional variations in sex ratios at birth are characterized largely by a divide between west and east according to the Multiple Indicators Cluster Survey (MICS) 2009 report. In the eastern region, sex ratios at birth are skewed while the ratios lie within the normal range in the western region. Sex ratios are highly unbalanced $(>109)$ in two-thirds of the districts in the eastern region, while two-thirds of the districts in the western region have normal and near normal sex ratio (UNICEF 2011).

Three factors underlie unbalanced sex ratios at birth as postulated by Guilmoto (2009): strong son preference, declining or low fertility, and the availability of pre-natal diagnostic techniques that reveal the sex of the fetus. All three conditions are present in Bangladesh, with varying intensity.

\footnotetext{
2 Normally more boys are born than girls in nature to compensate for the higher mortality of males; the expected natural sex ratio is, therefore, considered 105 boys for every 100 girls born. Analysis of the DHS data suggests that the sex ratio at birth remained almost same at 103 male per 100 female newborns in the past two decades in Bangladesh.
} 
Access to sex-selection technology moderately exists in Bangladesh. Ultrasound is the only available technology for prenatal sex detection in Bangladesh ${ }^{3}$. This technology is not commonly used in Bangladesh for sex selection despite the absence of any law forbidding the use of such technology. There is an absence of official evidence on the use of ultrasound technology to detect the sex of a fetus. Several studies have indicated a low use of ultrasound technology for sex-detection and even fewer noted its use for sex-selective abortion. The study by Gipson and Hindin (2008) suggests that ultrasound is hardly used for sex determination. Many women had ultrasound scanning but largely to check the health and position of the fetus. Like many developing countries, ultrasound is not widely used for sex determination in Bangladesh (Huq et al. 2012).

Although ultrasound is widely used to monitor the growth of the fetus, there is little evidence suggesting that it is used for reasons of sex selection; indeed, while menstrual regulation (MR) is permitted up to 10 weeks of pregnancy, termination of pregnancy thereafter, when the sex of the fetus can be detected through ultrasound, is highly restricted. Overall, the rate of pregnancy termination is high in the country. In a recent study, Vlassoff et al. (2012) estimated that 653,100 MR procedures were performed in health facilities nationwide in 2010. In addition, an estimated 646,600 induced abortions were performed, the majority of which were unsafe (Vlassoff et al. 2012). Skewed SRBs are typically associated with high rates of pregnancy termination. Bangladesh appears to be characterized by a contrast between normal SRB and higher incidence of pregnancy termination; therefore it would be interesting to see whether any sex-selective abortion exists. How effectively abortion law is implemented remains to be examined.

Unavailability of advanced prenatal diagnostic technology for sex selection within early gestational period, and use of ultrasound technology in the later part of pregnancy for checking the health of fetus, are possible reasons for limited incidence of sex-selective abortion. Although skewed sex ratios at birth are typically associated with high rates of abortion, the eastern region of Bangladesh presents a paradox where the skewed sex ratios at birth coexist with lowest level of pregnancy termination (menstrual regulation) (Talukder et al. 2014).

Two other conditions-son preference and low fertility-are clearly present in Bangladesh. The total fertility rate is now 2.3 (NIPORT et al. 2015); son preference and gender-biased family-building strategies are practiced (Talukder et al. 2014). Indeed, the sex composition of children already born is found to influence couple's decision to use contraceptive methods or to have an additional child. Couples who are motivated by the desire to have sons rather than daughters continue childbearing until reaching their desired number of son(s) and stop childbearing after that. However, there is little evidence that strong son preference has been translated into gender-biased sex selection (Talukder et al. 2014).

In the context of a traditional culture of male-child preference among couples in Bangladesh, recent changes in gender preference are encouraging. There is a strong preference for balanced gender of children, which is becoming a common norm over time across the country. Those who had at least

\footnotetext{
3 The country is yet to introduce any technology for testing the DNA of fetuses for prenatal sex determination within the early gestational period.
} 
one son and a daughter had the lowest fertility (Saha and Bairagi 2007). The popularity of "one boy and one girl' composition is nearly universal as only 9 percent of the women with such a balanced sex composition of children want an additional child in future. Moreover, the preference for higher number sons than daughters has decreased remarkably over the past two decades while the preference for higher number daughters than sons has remained same over the period (Talukder et al. 2014). Thus, a culture of son preference appears to be giving way to a growing indifference to the sex of a child.

Indicators of women's relative position in Bangladesh have slowly improved over the last 20 years. The improved conditions of female population are reflected in their improved access to education, healthcare, employment, and credit opportunities in the country.

The country has implemented several programs intended to change gender role attitudes that favor boys. For example, cash and non-cash transfer programs are implemented to raise the value of girls, ensure their educational status and delay their marriage. The increase in the rate of girls' enrollment in secondary schools is believed to have been brought about by a cash transfer program implemented by the government in rural areas (Khandker et al. 2003; Asadullah and Chaudhury 2006; KFW 2006; Islam and Dogra 2011). Introduced in 1994, the nationwide secondary-school stipend program incentivizes families to delay their daughters' marriages. The female-stipend program has not been rigorously evaluated to assess its impact in delaying child marriage. Whether Bangladesh's success in educating its female population reduces the preference for sons requires deeper investigation.

In recent years, there has been a significant change in attitude toward women taking up outside employment. Rapid expansion of the labor-intensive apparel industry and a high penetration of microfinance are two key reasons behind the higher participation rate of the female workforce in Bangladesh (Talukder et al. 2014). Women's participation in the labor force is higher than ever. Still, female labor force participation remains remarkably lower compared to that of male (BBS 2011). Policies and strategies are in place to ensure equal opportunities between men and women, but these are yet to be fully utilized. It is also important to know whether improved employment and economic opportunities for women influence couple's preferences of sons over daughters.

Bangladesh is the exception to the traditional situation in which son preference often leads to higher mortality among girls than boys. Female disadvantage in mortality has declined substantially since the 1990s. The gap in neonatal and infant mortality rates between males and females has been widened in favor of females, resulting in higher mortality among male children than female children. Male neonates have a mortality rate of 39 per 1,000 live births, compared with 26 for female counterparts. Fewer female infants die before their first birthday than male infants (infant mortality is 37 for female children and 48 for male children) (NIPORT et al. 2013). These remarkable improvements in the survival of girls over boys suggest a lessening of discrimination toward the girlchild.

The government's strong advocacy for a two-child family norm for more than three decades is believed to have brought changes in the demand for small family size in the country. The role of the mass media in changing fertility levels is well recognized and documented (Talukder et al. 2014), but 
evidence is lacking on media initiatives that change the value of daughters, reduce discrimination against daughters, or affect the sex composition of children.

Until now, Bangladesh has not experienced high SRB and therefore has not taken any actions to reduce SRB by banning sex-selective abortion as is the case for several developing countries in Asia, including China, India, and South Korea. The need for policies/laws on the use of prenatal diagnostic techniques for sex selection is yet to be realized by policymakers in Bangladesh.

Recognizing these gaps in understanding, the Population Council's Bangladesh office, led by the Council's India office, has undertaken a primary research study that assesses the factors underlying regional differences in sex ratio at birth in Bangladesh and makes recommendations to inform the design of programs intended to raise the value of girls and counter the practice of gender-biased sex selection, if any. This primary research focuses on the mechanisms underlying the variations in the sex ratio at birth through which couples implement their preference for sons. 


\section{METHODOLOGY}

\section{Study purpose}

The goal of this study was to identify factors underlying the disparities in sex ratios at birth in some parts of Bangladesh, by comparing the situation in districts with high and normal sex ratios at birth.

\section{Study location}

Two districts were purposively chosen: Comilla from the eastern region where sex ratios were adverse and Rangpur from the western region which had normal sex ratio. The study was located in rural and urban areas of these two contrasting districts of Bangladesh.

Comilla district, located in the eastern region of the country, has a population of 5.38 million, with the density of 1,700 per square kilometer. The district is administratively divided into 16 subdistricts and then 184 unions (lowest-level administrative unit with a population of approximately 30,000 each). There are 3,687 villages in the district. Comilla town consists of 18 wards, divided into 46 mohallas. The town contains a population of 0.17 million in an area of 12 square kilometer. Sixty-one percent of the district population is literate, while no notable difference exists between male and female (63\% vs. $59 \%$ ). In the district, total number of women of reproductive age is 1.34 million and the total annual live births is 105,336 . Total fertility rate (TFR) of Comilla is 2.4 (BBS 2011). Sex-ratio at birth in Comilla is 117 and under-five sex ratio is 112 (UNICEF 2011).

Located in the western region of Bangladesh, Rangpur district has a population of 2.88 million where 1,200 people live per square kilometer, according to the 2011 Census. The district consists of 8 subdistricts, and 84 unions. The urban area has 33 wards and 203 mohallas. Rangpur town covers an area of around 43 square kilometers, and is the home to a population of 0.25 million. The literacy rate of the district is 54 percent, while there is a small difference between male and female (57\% vs. 51\%). The district has 0.76 million women of reproductive age and 54,101 babies are born annually. The TFR of the district stands at 2.1 (BBS 2011). Rangpur has sex-ratio at birth of 105 and underfive sex ratio of 104 (UNICEF 2011).

\section{Study design}

The study employed both quantitative and qualitative methods to draw insights from a diverse set of individuals. Broadly, the study consisted of: (i) a household listing exercise to identify married women with at least two children, one of whom was born in five years preceding the interview; (ii) a household survey with married women, drawn from eligible respondents identified through household listing exercise; (iii) key informant interviews with healthcare providers (obstetriciansgynecologists, radiologists, nurses and female paramedics); and (iv) key informant interviews with program implementers/managers at government and non-governmental organization (NGO) levels. 


\section{Sampling and data collection}

\section{QUANTITATIVE DATA COLLECTION}

A household survey was conducted to understand the reasons for differentials in sex ratio at birth across regions and whether boys get more priorities than girls in the family; to learn about women's experiences of pregnancy, including the tests they have undergone during pregnancy; and to know the value of girl child and about the existing governmental and non-governmental programs for the welfare of girl children.

Survey respondents were drawn from both urban and rural areas of two study districts. The household survey used a multistage random sampling method to get the required samples. In each district, 20 clusters ( 10 from urban and 10 from rural) were selected at random, and 25 respondents were selected from each cluster. A total of 40 clusters were selected from 2 districts to interview currently married women with at least two children whose youngest child is 0-5 years old at the time of survey. The research team interviewed 1,037 women from two districts.

(i) Urban. In Bangladesh, a municipality area is divided into "wards" and then into "mohallas". The municipality area from the selected districts served as urban site for the study. From the municipality area, three wards were selected at random, followed by the random selection of 3-4 mohallas (using Probability Proportional to Size [PPS]) from each ward. A total of 10 mohallas were selected from three wards in each urban area to collect information from 250 eligible women.

Prior to collecting data in urban areas, household listing was completed to construct the sample frame. A cluster containing up to approximately 200 households in each mohalla was enumerated in order to select 25 eligible women. A total of 25 respondents from each cluster were randomly selected.

(ii) Rural. Generally, a district has nine rural upazillas (depending on the size of the district), and each upazilla is divided into "unions" and then into "villages". First, one upazilla was selected at random from each of the study districts. Then, from the selected upazilla, three unions were randomly chosen. The next stage comprised the selection of 3-4 villages from each union through PPS. Thus, a total of 10 villages from 3 unions of one upazilla each from two districts served as rural sites for data collection.

In rural areas, the list of eligible couples prepared and updated routinely by government family planning outreach workers (who provide doorstep services) was utilized to construct the sample frame. Generally, a village contains 150-250 households, so in the survey a village served as a rural cluster. In line with selection criteria, a list of eligible women for each of the 10 study villages was prepared, and then 25 respondents were randomly selected from each village. 
In total, 1,100 eligible women were identified and 1,037 of these women were interviewed, yielding a response rate of 94 percent overall. All women were interviewed at their home.

Table 1: Coverage of the household survey

\begin{tabular}{lcrr} 
& \multicolumn{2}{c}{$\begin{array}{c}\text { Number of married women with at least two children, } \\
\text { one of whom was aged 0-5 }\end{array}$} & $\begin{array}{r}\text { Response } \\
\text { rate }\end{array}$ \\
\cline { 2 - 3 } District and site & Identified & Interviewed & \\
\hline Comilla & & & 92.1 \\
$\quad$ Rural & 279 & 257 & 95.9 \\
$\quad$ Urban & 271 & 260 & 94.0 \\
Total & 550 & 517 & \\
\hline Rangpur & & & 96.3 \\
$\quad$ Rural & 270 & 260 & 92.9 \\
$\quad$ Urban & 280 & 260 & 94.6 \\
Total & 550 & 520 & 94.3 \\
\hline Total Sample & 1,100 & 1,037 & \\
\hline
\end{tabular}

\section{QUALITATIVE DATA COLLECTION}

Key informant interviews (KIIs) were conducted with two groups of respondents: service providers and program implementers. Key informant interviews were held with providers in both government and private facilities who are knowledgeable about such issues as gender-biased sex selection or sex-selective abortion, for example, obstetrician-gynecologists, radiologists, nurses and female paramedics. The purpose of this KII was to better understand providers' own perceptions about termination of pregnancies carrying a female fetus, the extent to which they believe this to be a common practice, the extent to which the practice may have reduced or increased over time, the perceived role of the authorities and so on. A total of 32 service providers, including doctors and midlevel providers (nurses and female paramedics), were interviewed from two study districts.

In addition, 12 program implementers/managers who are responsible for the implementation of a range of activities-programs for girls, community mobilization and advocacy-at government and NGO levels were interviewed. Government officials were selected from those engaged in monitoring the adherence to implementing school stipend for girls and development programs for women. From the non-governmental sector, interviews were held with those engaged in local and national level advocacy, and those involved in mobilizing communities at the district and higher levels. A total of 12 program implementers were interviewed at both national and district levels: 5 from Dhaka city that generally houses organizational head offices and 7 interviews from two study districts. 
Table 2: Coverage of the key informant interviews

\begin{tabular}{lrrrr}
\hline Types of respondents & Comilla & Rangpur & National & Total \\
\hline $\begin{array}{l}\text { A. Healthcare providers } \\
\text { District administrator for health and family planning/ }\end{array}$ & 3 & 1 & - & 4 \\
$\quad$ Doctor & & & & \\
$\quad$ Radiologist & 2 & 4 & - & 6 \\
Obstetrician-gynecologist & 4 & 5 & - & 9 \\
Mid-level provider (nurse/paramedic) & 7 & 6 & - & 13 \\
Total & 16 & 16 & - & 32 \\
B. Program implementers/managers & & & & \\
Government program implementer & 3 & 2 & 2 & 7 \\
$\quad$ NGO program manager & 1 & 1 & 3 & 5 \\
Total & 4 & 3 & 5 & 12 \\
\hline
\end{tabular}

\section{Data analysis}

Analysis of quantitative data focuses on comparing the situation in contrasting study districts and highlights factors underlying the disparities in sex ratios. Textual data from in-depth interviews were transcribed, and thematic analysis of textual data focuses on perceptions about the prevalence of gender-biased sex selection, the practices of service providers with regard to gender-biased sex selection (if any), the use of ultrasound to determine the sex of the fetus, factors accounting for the rise in the sex ratio at birth (if any), the impact of the programs intended to raise the value of girls and reduce son preference, and so on.

\section{Ethical considerations}

Risks and benefits to subjects and confidentiality. The study offered minimal risk in terms of data collection from human subjects. To avoid the potential risk that something that a respondent says during the interview is overheard, the research team ensured that the interview takes place in complete privacy and terminating the interview if privacy cannot be guaranteed. Interviewers were selected according to their ability and experience with the topics, and their training included a strong emphasis on informed consent so that they were able to put the client at ease when asking questions and to maintain privacy and confidentiality.

A unique identification number was given to every woman selected for the household survey to ensure anonymity of the subjects. For key informant interviews, respondents were assured that all information including disclosure of violation of the law that he or she provides (if any) will be kept confidential.

Compensation. Participation in the survey was entirely voluntary. No incentives or compensation was paid to respondents for taking part. 
Informed consent. Structured verbal consent form was used in one-to-one interviews and the respondents were informed about the study objectives, time needed for the interview, and risks and benefits. Potential participants were assured that they have the right to withdraw from the interview at any point in time. They were also informed that they have the right to refuse to answer any or all of the questions, even after consenting to participate in the study. Survey respondents were informed that as part of the Population Council's policy on adherence to ethical procedures, a representative of the Population Council might request a private interview to confirm that the participant was properly informed about the study and procedure before giving consent. After being fully informed about the study objectives, procedures, benefits and risks, respondents were asked to give verbal consent if they wished to participate in the study. Interviewers attested to their verbal informed consent to participate. All respondents were given the interviewer's and the principal investigator's phone numbers and told that if they had any questions or concerns or problems, they should contact these individuals. 


\section{SEX RATIOS, GENDER PREFERENCE, AND SEX SELECTION}

In Bangladesh, regional variations in sex ratio at birth (SRB) are characterized by an east-west divide. The Multiple Indicators Cluster Survey (MICS) 2009 report ${ }^{4}$ noted a clear east-west divide in terms of sex composition of children born. Women from three western divisions (Khulna, Rajshahi and Rangpur) had sex ratio at birth not exceeding the normal level of 105 while sex ratio in the eastern divisions (Sylhet and Chittagong) had a highly unbalanced composition of boys over girls (>109). According to 2011 BDHS data ${ }^{5}$, the western region had fewer boys than girls at birth (SRB: 97) while the eastern region had more boys than girls (SRB: 104). To understand the factors that contribute to regional variations in the sex ratio at birth, the present study included a household survey among married women aged 18-49 years who had at least two living children, the youngest of whom was 5 years old. The study was located in two contrasting districts of Bangladesh: one with adverse sex ratio (Comilla district from the eastern region) and other with normal sex ratio (Rangpur district from the western region). The following discussions highlight the key findings from this household survey.

\section{A. Women's profile}

The distribution of women in terms of age groups is nearly the same across study districts. Less than one percent of women surveyed were aged below 19 years. Two-thirds of women were aged 20-29 years and another one-fourth was between 30 and 34 years. Women older than 40 years constituted only one percent of the respondents. More than 90 percent of women surveyed were Muslim and the concentration of Muslim population was higher in Comilla than in Rangpur (Table 3).

Overall, education level is higher in Comilla than in Rangpur. Comilla, where sex ratios were distorted, exhibited higher levels of educational attainment than Rangpur with normal sex ratio at birth. Approximately, half of the women completed primary education with notable urban-rural difference within the district. A large district-level and urban-rural difference existed among women completing secondary and higher education. Twenty-four percent of women completed secondary and higher education in Comilla compared to 13 percent in Rangpur (Table 3).

Labor force participation is low, comprising 3 to 20 percent of women. More women in Rangpur than in Comilla were involved with any economic activities. Women from rural Comilla were least likely to participate in any economic activities (3\%). The distribution of women by socio-economic status reveals that Comilla is wealthier than Rangpur. More than half of the women from Comilla belonged to the upper two wealth groups while in Rangpur the lower two wealth groups contained 54 percent of women. As expected, urban-rural gap within each wealth group of the district was substantial (Table 3).

\footnotetext{
${ }^{4}$ MICS study was conducted by the Bangladesh Bureau of Statistics (BBS) and the report published by UNICEF.

5 BDHS 2011 had a total sample of almost 18,000 and within the last calendar year of the survey over 1,700 births were reported, which constitutes the sample size for analyzing sex ratio at birth. Caution should be exercised in interpreting the findings that originate from these data as the size of samples may not be adequate to provide a definitive conclusion.
} 
Table 3: Selected background characteristics of women by sites

\begin{tabular}{|c|c|c|c|c|c|c|}
\hline \multirow{2}{*}{ Background characteristics } & \multicolumn{2}{|c|}{ Urban } & \multicolumn{2}{|c|}{ Rural } & \multicolumn{2}{|c|}{ Total } \\
\hline & Comilla & Rangpur & Comilla & Rangpur & Comilla & Rangpur \\
\hline \multicolumn{7}{|l|}{ Age group } \\
\hline $18-19$ & 1.2 & 0.8 & 0.8 & 0.8 & 1.0 & 0.8 \\
\hline $20-24$ & 17.9 & 23.8 & 23.5 & 23.1 & 20.7 & 23.5 \\
\hline $25-29$ & 43.6 & 45.8 & 43.8 & 42.3 & 43.7 & 44.0 \\
\hline $30-34$ & 25.7 & 20.8 & 23.8 & 25.4 & 24.8 & 23.1 \\
\hline $35-39$ & 10.1 & 8.8 & 8.1 & 6.5 & 9.1 & 7.7 \\
\hline $40-49$ & 1.6 & - & - & 1.9 & 0.8 & 1.0 \\
\hline Total & 100.0 & 100.0 & 100.0 & 100.0 & 100.0 & 100.0 \\
\hline Mean (years) & 28.3 & 27.7 & 27.7 & 28.0 & 28.0 & 27.9 \\
\hline \multicolumn{7}{|l|}{ Religion } \\
\hline Muslim & 93.4 & 87.3 & 98.5 & 94.2 & 95.9 & 90.8 \\
\hline Non-Muslim & 6.6 & 12.7 & 1.5 & 5.8 & 4.1 & 9.2 \\
\hline Total & 100.0 & 100.0 & 100.0 & 100.0 & 100.0 & 100.0 \\
\hline \multicolumn{7}{|l|}{ Educational attainment } \\
\hline No education & 10.5 & 16.9 & 9.2 & 34.2 & 9.9 & 25.6 \\
\hline Primary incomplete & 8.9 & 13.8 & 19.2 & 21.2 & 14.1 & 17.5 \\
\hline Primary complete & 42.4 & 50.4 & 61.2 & 37.3 & 51.8 & 43.8 \\
\hline Secondary complete & 15.6 & 12.3 & 6.9 & 5.0 & 11.2 & 8.7 \\
\hline Graduate and above & 22.6 & 6.6 & 3.5 & 2.3 & 13.0 & 4.4 \\
\hline Total & 100.0 & 100.0 & 100.0 & 100.0 & 100.0 & 100.0 \\
\hline Employed & 10.5 & 18.5 & 3.1 & 20.4 & 6.8 & 19.4 \\
\hline \multicolumn{7}{|l|}{ Wealth quintile } \\
\hline Lowest & - & 17.7 & 16.5 & 45.8 & 8.3 & 31.7 \\
\hline Second & 10.5 & 16.2 & 26.9 & 27.7 & 18.8 & 21.9 \\
\hline Middle & 16.7 & 19.2 & 22.7 & 15.0 & 19.7 & 17.1 \\
\hline Fourth & 25.3 & 31.5 & 18.5 & 8.8 & 21.9 & 20.2 \\
\hline Highest & 47.5 & 15.4 & 15.4 & 2.7 & 31.3 & 9.0 \\
\hline Total & 100.0 & 100.0 & 100.0 & 100.0 & 100.0 & 100.0 \\
\hline $\mathrm{N}$ & 257 & 260 & 260 & 260 & 517 & 520 \\
\hline
\end{tabular}


Table 4 shows gender role attitudes among women which were assessed by questions ascertaining whether women supported girls' education, right to decide about their own marriage, and right to make household decisions once married. Findings suggest that the majority of women held genderegalitarian attitudes. For example, almost all the respondents agreed that a girl should study as much as she wants, 74 percent supported girls' rights to make marriage decisions, and as many as 93-97 percent believed that both husband and wife should make decisions on how to spend household money. District-level comparison shows no difference.

Table 4: Perception about gender role among married women of reproductive age (in percent)

\begin{tabular}{lrrrrrr}
\hline \multirow{2}{*}{ Attitude variable } & \multicolumn{2}{c}{ Urban } & \multicolumn{2}{c}{ Rural } & \multicolumn{2}{c}{ Total } \\
\cline { 2 - 7 } & Comilla & Rangpur & Comilla & Rangpur & Comilla & Rangpur \\
\hline $\begin{array}{l}\text { A girl should study as much as } \\
\text { she wants }\end{array}$ & 97.7 & $100.0^{*}$ & 98.5 & 99.6 & 98.1 & $99.8^{* *}$ \\
$\begin{array}{l}\text { Girls should be allowed to decide } \\
\text { when they want to marry }\end{array}$ & 71.6 & $84.2^{* *}$ & 75.4 & $63.1^{* *}$ & 73.5 & 73.7 \\
$\begin{array}{l}\text { Husband alone/mainly should } \\
\text { decide how to spend household } \\
\text { money }\end{array}$ & 4.3 & 4.2 & 10.0 & $1.9 * * *$ & 7.2 & $3.1^{* *}$ \\
$\mathrm{~N}$ & 257 & 260 & 260 & 260 & 517 & 520 \\
\hline
\end{tabular}

* Significant at $0.05, * *$ Significant at $0.01, * * *$ Significant at 0.001

Three questions were posed to measure the mobility of women, and analysis shows greater mobility of women in Comilla (district with skewed sex ratio at birth) than in Rangpur (district with normal sex ratio at birth). Findings presented in Table 5 show that the majority of women were allowed to go to a meeting or a program and women from Comilla are more likely to enjoy such autonomy than those from Rangpur ( $68 \%$ vs. $55 \%$ ). The freedom to visit a friend or relative outside village/mohalla is widespread across study districts, ranging from 77 in rural Rangpur to 90 percent in rural Comilla. Mobility to go to an entertainment event is reported by only 38 percent of women from Rangpur while it is higher for Comilla (59\%). Greater mobility for Comilla indicates progress in the attitude towards females in the district.

As shown in Table 5, one-fifth of women or less have ever done any paid work, which is remarkably low and reflects a limited improvement in the attitude towards women taking up paid employment. Women's participation in labor force is higher in urban than in rural area. The proportion of women who had ever done any paid work in Rangpur (23\%) is roughly twice that in Comilla (13\%). On the other hand, women in Comilla are twice as likely to have a bank account as those in Rangpur (22\% vs. $10 \%$ ), which is primarily due to the fact that many women from Comilla have husbands working abroad (not shown in the table). Women from Comilla enjoy greater autonomy in terms of operating the account than from Rangpur (94 percent vs. 83 percent). Urban-rural difference in operating the account independently is small. 
Table 5: Female autonomy in mobility and financial empowerment (in percent)

\begin{tabular}{|c|c|c|c|c|c|c|}
\hline \multirow{2}{*}{ Indicator } & \multicolumn{2}{|c|}{ Urban } & \multicolumn{2}{|c|}{ Rural } & \multicolumn{2}{|c|}{ Total } \\
\hline & Comilla & Rangpur & Comilla & Rangpur & Comilla & Rangpur \\
\hline \multicolumn{7}{|l|}{ Mobility } \\
\hline $\begin{array}{l}\text { Allowed to go to a meeting } \\
\text { or a program }\end{array}$ & 68.1 & 65.8 & 68.1 & $44.6 * * *$ & 68.1 & $55.2 * * *$ \\
\hline $\begin{array}{l}\text { Allowed to go to visit a } \\
\text { friend or relative outside } \\
\text { village/mohalla }\end{array}$ & 81.7 & 77.7 & 89.6 & $77.3 * * *$ & 85.7 & $77.5 * *$ \\
\hline $\begin{array}{l}\text { Allowed to go to an } \\
\text { entertainment event }\end{array}$ & 65.8 & $54.2 * *$ & 52.7 & $21.5^{* * *}$ & 59.2 & $37.9 * * *$ \\
\hline $\mathrm{N}$ & 257 & 260 & 260 & 260 & 517 & 520 \\
\hline \multicolumn{7}{|l|}{ Financial empowerment } \\
\hline Ever done any paid work & 18.3 & 24.2 & 8.5 & $21.9 * * *$ & 13.3 & $23.1 * * *$ \\
\hline $\begin{array}{l}\text { Have an bank account in } \\
\text { own name or jointly with } \\
\text { someone else }\end{array}$ & 26.8 & $17.7 *$ & 17.3 & $3.1 * * *$ & 22.1 & $10.4 * * *$ \\
\hline $\mathrm{N}$ & 257 & 260 & 260 & 260 & 517 & 520 \\
\hline $\begin{array}{l}\text { Operate the account } \\
\text { independently }\end{array}$ & 92.8 & 82.6 & 95.5 & 87.5 & 93.8 & $83.3 *$ \\
\hline $\mathbf{N}$ & 69 & 46 & 44 & 8 & 113 & 54 \\
\hline
\end{tabular}

* Significant at 0.05, ** Significant at 0.01, * ** Significant at 0.001

\section{B. Factors underlying regional differences in sex ratios}

This section explores factors affecting sex ratios in Comilla and Rangpur, from survey and textual data drawn from women and key informants respectively. District-wise sex ratios of children ever born and surviving from household survey are not provided in this report, because the sample is too small to provide reliable estimates of sex ratios, and because it was restricted to a subgroup of women who had two or more children, the youngest of whom was born in the five years preceding the survey.

From the survey of women with two or more children, one of whom was aged 0-5 years at the time of the survey, we focus on each of the three preconditions identified by Guilmoto (2011) as key in accounting for skewed sex ratios at birth, namely, preference for small families, persistent strong son preference, and access to pre-natal diagnostic technology. In addition, the perspectives of key informants relating to two of these three preconditions, namely, persistent strong son preference and access to pre-natal diagnostic technology, were discussed. 


\section{DEMOGRAPHY OF SON PREFERENCE}

\section{Ideal number and composition of children}

Family size preferences suggest that the two-child norm is widely embraced by women in both districts (Table 6). More than 80 percent of women reported a preference for two children, and some 2-4 percent for just one child. The proportion of women preferring a two-child family is highest in urban Rangpur (92\%), followed by rural Rangpur and urban Comilla (86\%). A three-child family was desired by 10 percent of women in Comilla and 7 percent of those in Rangpur; however, rural-urban differences were notable, with 4-5 percent of urban women, and 9-14 percent of rural women considering three children as ideal. Only 2 percent of women desired a four-child or larger family, indicating the reluctance of women to bear many children.

Table 6: Ideal number of children among women by sites (in percent)

\begin{tabular}{lrrrrrr}
\hline & \multicolumn{2}{c}{ Urban } & \multicolumn{2}{c}{ Rural } & \multicolumn{2}{c}{ Total } \\
\cline { 2 - 7 } Indicator & Comilla & Rangpur & Comilla & Rangpur & Comilla & Rangpur \\
\hline Ideal number of children & & & & & & \\
$\quad 1$ & 5.8 & 2.7 & 2.3 & 1.2 & 4.1 & 1.9 \\
2 & 86.0 & 92.3 & 82.3 & 86.5 & 84.1 & 89.5 \\
3 & 5.4 & 3.8 & 13.5 & 9.2 & 9.5 & 6.5 \\
4 and above & 2.8 & 1.2 & 1.9 & 3.1 & 2.3 & 2.1 \\
Total & 100.0 & 100.0 & 100.0 & 100.0 & 100.0 & 100.0 \\
N & 257 & 260 & 260 & 260 & 517 & 520 \\
Mean & 2.05 & 2.03 & 2.15 & 2.15 & 2.10 & 2.09 \\
\hline
\end{tabular}

Figure 1 shows the composition of children among women expressing different fertility ideals. Indifference to the sex of child was evident among women preferring one-child family, which is encouraging in the context of the patriarchal culture of the country. Overall, most women (70-71\%) claimed to have no gender preference when only one child is desired. The distribution of women mentioning a two-child ideal shows a strong desire for one boy and one girl in both study sites-women from Rangpur were more likely to express such preference than those from Comilla (97\% versus $89 \%)$. Son preference was almost absent among women expressing 2-child ideal, but it becomes prominent with increasing fertility ideals. There was a strong preference for sons over daughters among women mentioning three-child as ideal: 74-80 percent of women considered two sons and one daughter as ideal (Figure 1). Son preference was more likely to be stated by women in rural than urban areas (not shown in the figure). Variations between districts are small. For 4-child and above fertility ideals, son preference plummeted. Among women who desired a four-child family, the vast majority wanted a balanced composition of two boys and two girls (Figure 1). 
Figure 1: Perceived gender preference among women by fertility ideals (in percent)

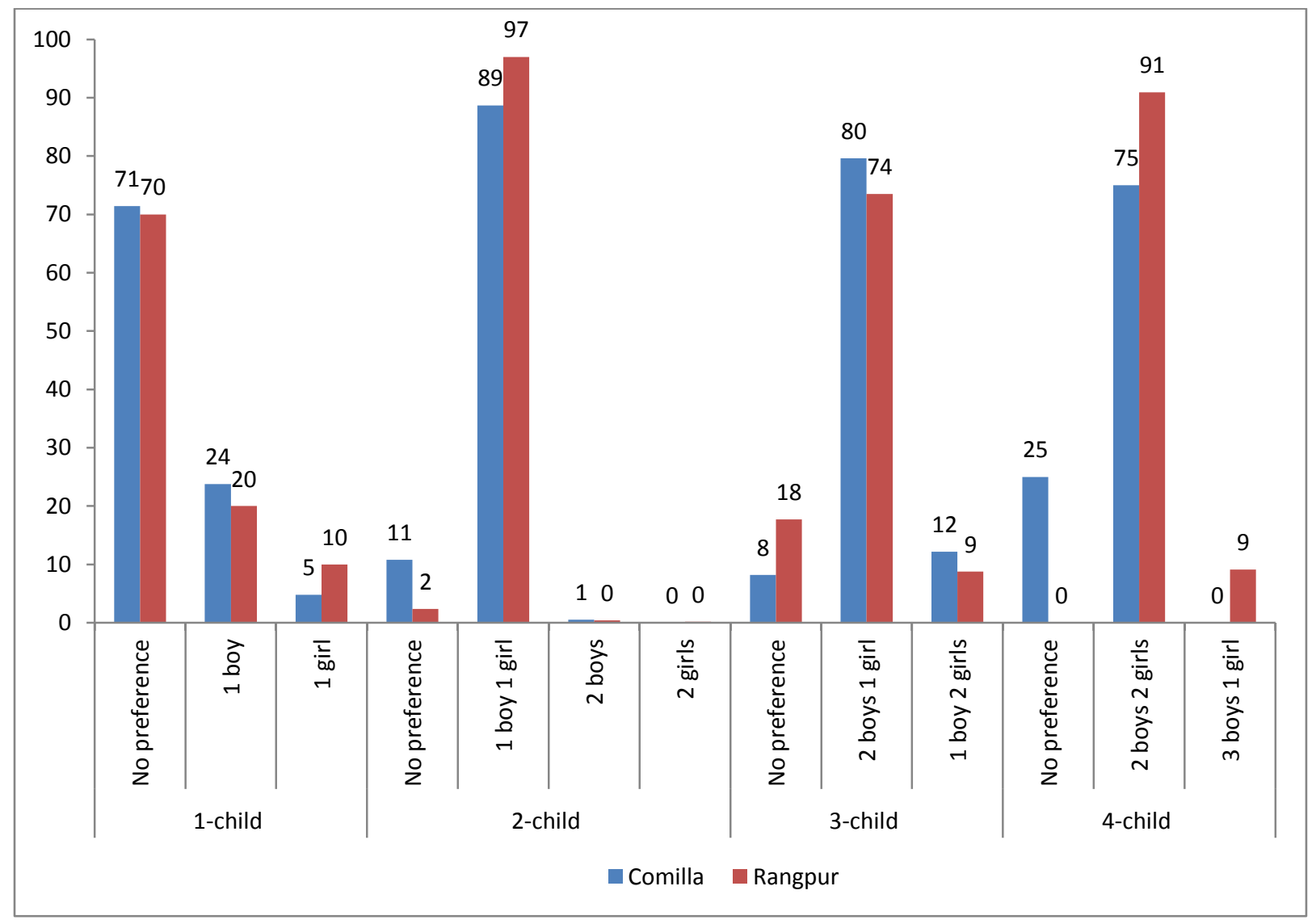

Note: Differences between two districts are significant at $p<0.001$ for two-child fertility ideal

\section{Emergence of a small-family norm}

Women's desire to have a small family is reflected in their actual fertility. Small family sizes were widely reported. On average, women from Comilla reported having 2.6 living children while it is 2.5 for Rangpur, with urban respondents reporting marginally smaller numbers of children (2.4-2.5) than did rural respondents (2.7). It is to be noted that the study included those women who had at least two surviving children at the time of survey, and findings suggest that at least half of the respondents mentioned having two living children. Specifically, the practice of having a small family (two living children) is stronger among urban women than among rural women. Another one-fourth had three living children. Having two children is more common in Rangpur than in Comilla (66\% vs. $55 \%$ ) while having three children is higher in Comilla than in Rangpur (34\% vs. 23\%). Overall, 11-13 percent had four or more children, and women from rural areas are more likely to have a large family (four children or beyond) than urban respondents (Table 7 ). 
Table 7: Distribution of women by their actual family size (in percent)

\begin{tabular}{|c|c|c|c|c|c|c|}
\hline \multirow{2}{*}{ Living children } & \multicolumn{2}{|c|}{ Urban } & \multicolumn{2}{|c|}{ Rural } & \multicolumn{2}{|c|}{ Total } \\
\hline & Comilla & Rangpur & Comilla & Rangpur & Comilla & Rangpur \\
\hline $\begin{array}{l}\text { Mean number of living } \\
\text { children }\end{array}$ & 2.5 & $2.4^{*}$ & 2.7 & 2.7 & 2.6 & 2.5 \\
\hline \multicolumn{7}{|l|}{ Living children } \\
\hline 2 & 61.1 & $72.7 *$ & 49.2 & $58.8 * *$ & 55.1 & $65.8 * * *$ \\
\hline 3 & 30.0 & 20.8 & 38.8 & 24.3 & 34.4 & 22.5 \\
\hline 4 or above & 8.9 & 6.5 & 12.0 & 16.9 & 10.5 & 11.7 \\
\hline Total & 100.0 & 100.0 & 100.0 & 100.0. & 100.0 & 100.0 \\
\hline$N$ & 257 & 260 & 260 & 260 & 517 & 520 \\
\hline
\end{tabular}

* Significant at $0.05, * *$ Significant at $0.01, * * *$ Significant at 0.001

\section{Living children composition among women not intending an additional child}

The large majority (81-87\%) wanted no more children, reiterating the strength with which the twochild norm was held among women in both districts. District-wise differences among women at different parities who do not intend to have an additional child were clearly present. Women from Rangpur with two children were more likely not to intend an additional child than those from Comilla (62\% vs. $47 \%)$ and such attitude is more intense among women in the urban setting. A reverse scenario existed among women with three children. Women from Comilla with three children were nearly twice as likely not to intend to have an additional child as women from Rangpur ( $41 \%$ vs. $25 \%)$. The share of women with four children and more not intending more children did not vary between districts; however, such attitude was more common in rural than in urban setting (Table 8).

Table 8 also shows the relationship between composition of living children and women's desire for an additional child. (Only women having two and three children were considered for the analysis.) Having balanced sex composition of children has emerged as the key driver for not intending an additional child. Among women who had two children, the women with balanced sex composition constituted the largest group who did not want any more children. Sex of the living children hardly had any impact on the intention to have more children among women who had either 2 boys or 2 girls.

Among women having three children, women not intending to have more children varied across districts. Fewer women from Comilla than Rangpur having more daughters than sons had expressed intention to have no additional child (Comilla 32\%, Rangpur: 47\%). On the other hand, women from Comilla having more sons than daughters were highly reluctant to have additional child (Comilla 50\%, Rangpur: 32\%) (Table 8). Thus, the intention to have an additional child was related to the sex of the living children among women having three children in Comilla. 
Table 8: Number and composition of living children among women who want no more children (in percent)

\begin{tabular}{|c|c|c|c|c|c|c|}
\hline \multirow{2}{*}{$\begin{array}{l}\text { Composition of living } \\
\text { children }\end{array}$} & \multicolumn{2}{|c|}{ Urban } & \multicolumn{2}{|c|}{ Rural } & \multicolumn{2}{|c|}{ Total } \\
\hline & Comilla & Rangpur & Comilla & Rangpur & Comilla & Rangpur \\
\hline $\begin{array}{l}\text { Don't want more } \\
\text { children }\end{array}$ & 83.7 & 88.5 & 79.2 & $86.2 *$ & 81.4 & $87.3 * *$ \\
\hline $\mathrm{N}$ & 257 & 260 & 260 & 260 & 517 & 520 \\
\hline \multicolumn{7}{|c|}{ Number of living children } \\
\hline 2 & 54.9 & $70.9 * *$ & 38.3 & $52.7 * * *$ & 46.8 & $61.9 * * *$ \\
\hline 3 & 34.4 & 21.7 & 47.1 & 27.7 & 40.6 & 24.7 \\
\hline 4 & 8.4 & 6.1 & 12.1 & 12.1 & 10.2 & 9.0 \\
\hline Above 4 & 2.3 & 1.3 & 2.5 & 7.6 & 2.4 & 4.4 \\
\hline Total & 100.0 & 100.0 & 100.0 & 100.0 & 100.0 & 100.0 \\
\hline $\mathrm{N}$ & 215 & 230 & 206 & 224 & 421 & 454 \\
\hline \multicolumn{7}{|c|}{ Composition of living children } \\
\hline \multicolumn{7}{|l|}{ 2-child } \\
\hline 2 boys & 17.8 & 23.9 & 22.8 & 22.0 & 19.8 & 23.1 \\
\hline 2 girls & 20.3 & 19.0 & 13.9 & 16.1 & 17.8 & 17.8 \\
\hline 1 boy, 1 girl & 61.9 & 57.1 & 63.3 & 61.9 & 62.4 & 59.1 \\
\hline Total & 100.0 & 100.0 & 100.0 & 100.0 & 100.0 & 100.0 \\
\hline$N$ & 118 & 163 & 79 & 118 & 197 & 281 \\
\hline \multicolumn{7}{|l|}{ 3-child } \\
\hline 2 boys, 1 girl & 45.9 & 28.0 & 52.6 & 35.5 & 49.7 & $32.1^{*}$ \\
\hline 1 boy, 2 girls & 32.5 & 40.0 & 32.0 & 51.6 & 32.2 & 46.5 \\
\hline 3 boys & 10.8 & 14.0 & 6.2 & 4.8 & 8.2 & 8.9 \\
\hline 3 girls & 10.8 & 18.0 & 9.2 & 8.1 & 9.9 & 12.5 \\
\hline Total & 100.0 & 100.0 & 100.0 & 100.0 & 100.0 & 100.0 \\
\hline$N$ & 74 & 50 & 97 & 62 & 171 & 112 \\
\hline
\end{tabular}

* Significant at 0.05, ** Significant at 0.01, *** Significant at 0.001

\section{Future gender preference}

Even after having at least two children, a considerable proportion of women expressed their intention to have another child in future, and women from Comilla are more inclined to have an additional child than those from Rangpur (19\% vs. 13\%). Future fertility intention is greater among rural women than among their urban counterparts (Table 9).

A large gap exists in future intention to have children between women having more daughters than sons and women having more sons than daughters, in favor of the former, suggesting that they would be more likely to intend that a son is born to them in future. For example, half of the women having more daughters than sons or only daughters expressed their desire to have a child in future, while 27-33 percent of the women having more sons than daughters or only sons so reported. The distribution of women intending to have another child in future remains nearly same across the study districts. The proportion of women having a balanced sex composition of one son and one daughter intending to have another child is higher for Comilla (Table 9). 
Table 9: Future fertility intention among women

\begin{tabular}{|c|c|c|c|c|c|c|}
\hline \multirow{2}{*}{$\begin{array}{l}\text { Future fertility } \\
\text { intention }\end{array}$} & \multicolumn{2}{|c|}{ Urban } & \multicolumn{2}{|c|}{ Rural } & \multicolumn{2}{|c|}{ Total } \\
\hline & Comilla & Rangpur & Comilla & Rangpur & Comilla & Rangpur \\
\hline Want another child & 16.3 & 11.5 & 20.8 & $13.8 *$ & 18.6 & $12.7 * *$ \\
\hline $\mathrm{N}$ & 257 & 260 & 260 & 260 & 517 & 520 \\
\hline \multicolumn{7}{|c|}{ Current composition of child } \\
\hline 1 boy and 1 girl & 28.6 & 6.7 & 20.4 & 16.7 & 24.0 & 12.1 \\
\hline Boy-loaded $\dagger$ & 21.4 & 40.0 & 31.5 & 27.8 & 27.0 & 33.3 \\
\hline Girl-loaded $\ddagger$ & 50.0 & 53.3 & 48.1 & 55.5 & 49.0 & 54.6 \\
\hline Total & 100.0 & 100.0 & 100.0 & 100.0 & 100.0 & 100.0 \\
\hline $\mathrm{N}$ & 42 & 30 & 54 & 36 & 96 & 66 \\
\hline \multicolumn{7}{|l|}{1 boy and 1 girl } \\
\hline \multicolumn{7}{|c|}{ Gender preference for next children } \\
\hline Son & 2 & 1 & 4 & 2 & 6 & 3 \\
\hline Daughter & 2 & - & - & - & 2 & . \\
\hline No preference & 7 & 1 & 2 & 3 & 9 & 4 \\
\hline Upon God & 1 & 1 & 5 & 1 & 6 & 2 \\
\hline $\mathrm{N}$ & 12 & 3 & 11 & 6 & 23 & 9 \\
\hline \multicolumn{7}{|l|}{ Boy-loaded $\dagger$} \\
\hline \multicolumn{7}{|c|}{ Gender preference for next children } \\
\hline Son & - & - & - & - & - & - \\
\hline Daughter & 9 & 10 & 17 & 10 & 26 & 20 \\
\hline No preference & - & - & - & - & - & - \\
\hline Upon God & - & 1 & - & - & - & 1 \\
\hline $\mathrm{N}$ & 9 & 11 & 17 & 10 & 26 & 21 \\
\hline \multicolumn{7}{|l|}{ Girl-loaded $\ddagger$} \\
\hline \multicolumn{7}{|c|}{ Gender preference for next children } \\
\hline Son & 21 & 16 & 25 & 20 & 46 & 36 \\
\hline Daughter & - & - & - & - & - & - \\
\hline No preference & - & - & - & - & - & . \\
\hline Upon God & - & - & 1 & - & 1 & - \\
\hline $\mathrm{N}$ & 21 & 16 & 26 & 20 & 47 & 36 \\
\hline
\end{tabular}

†Boy-loaded includes: Two boys, one boy, and any combination having more boys than girls $\ddagger$ Girl-loaded includes: Two girls, one girl, and any combination having more girls than boys

Gender preference for future fertility is likely to be influenced by current composition of children. Women having a gender-balanced 2-child family were more likely to have no preference for the next child. Findings also suggest an emergence of a culture towards having a gender-balanced family among women irrespective of the sex of living children. A preference for son as a next child existed among women who had more daughters than sons as almost all these women wanted a boy child in future (girl-loaded group). Similarly, a clear preference for daughter was also expressed by women who had more sons than daughters (boy-loaded group). Preference for son or daughter does not vary across districts and by residence (Table 9). 


\section{Son preference}

Son preference expressed by women and their families is a critical pre-condition for skewed sex ratios at birth. The extent of son preference was measured by three indicators: the sex preference of children, future fertility intention, and use of contraception among women having two children. First, the proportion of women who did not express a preference for sons over daughters when asked about their ideal number of sons and daughters was calculated. For second and third indicators, the ratio of two quantities (the proportion of women having two sons compared with the proportion of women having two daughters) was estimated. If there was no preference for the sex of children, the ratio would be 1.0; and the higher the ratio, the stronger the son preference. Findings presented in Table 10 suggest that son preference prevails in both districts, while it is stronger in Comilla than in Rangpur.

In Bangladesh, a small proportion of women was indifferent about the sex of their children: 10 percent of the women with two living children in Comilla did not express a preference for the sex of the child, compared with 7 percent in Rangpur. This small difference between districts with distorted (Comilla) and normal sex ratios (Rangpur) does not imply that differences in the sex ratio at birth affected by the preference for the sex of children. Differences in the preference for the sex of children widen with place of residence within the district, yet these are inconsistent. In Comilla, more women from urban than rural reported that the sex of children did not matter to them. A reverse preference is noticed for Rangpur where more from rural than urban reported the same (Table 10).

Table 10: Indicators of son preference among women who have two living children

\begin{tabular}{|c|c|c|c|c|c|c|}
\hline \multirow{2}{*}{ Family size preference } & \multicolumn{2}{|c|}{ Urban } & \multicolumn{2}{|c|}{ Rural } & \multicolumn{2}{|c|}{ Total } \\
\hline & Comilla & Rangpur & Comilla & Rangpur & Comilla & Rangpur \\
\hline $\begin{array}{l}\text { Percentage who } \\
\text { expressed no } \\
\text { preference for the } \\
\text { sex of the child }\end{array}$ & 17.9 & 3.8 & 4.1 & 8.6 & 10.2 & 6.6 \\
\hline $\begin{array}{l}\text { Wanted no more } \\
\text { children among } \\
\text { those with } 2 \text { sons } \\
\text { versus } 2 \text { daughters } \\
\text { (ratio) }\end{array}$ & 1.30 & 1.16 & 1.49 & 1.44 & 1.30 & 1.27 \\
\hline $\begin{array}{l}\text { Currently using } \\
\text { contraception } \\
\text { among those with } 2 \\
\text { sons versus } 2 \\
\text { daughters (ratio) }\end{array}$ & 1.67 & 1.33 & 1.50 & 1.04 & 1.50 & 1.17 \\
\hline $\mathrm{N}$ & 157 & 189 & 128 & 153 & 285 & 342 \\
\hline
\end{tabular}


A second indicator of son preference measures the extent to which women's desire to continue childbearing depended on the sex composition of living children. In order to measure this, the proportion of women with two sons wanting no more children was compared with the proportion of women with two daughters wanting no more children. For this indicator, ratios of women who had two sons compared to those with two daughters reporting that they wanted no more children were similar across the study districts (Comilla: 1.30, Rangpur: 1.27); however, differences were wider in urban areas in favor of Comilla (Comilla: 1.30, Rangpur: 1.16).

The extent to which women's use of contraception was associated with the sex composition of their living children is used as an indirect way of measuring the influence of son preference on the family planning behavior of couples. A simple indicator was constructed which measures the ratio of the proportion of women with two sons currently using contraception with the proportion of women with two daughters using contraception. The ratio was higher in the district with distorted sex ratios (Comilla) than in the district with normal sex ratios (Rangpur) (1.50, 1.17 respectively). In Comilla, those with two sons were 50 percent more likely to have been practising contraception than those with two daughters, while in Rangpur they were 17 percent more likely to have done so. In particular, differences were pronounced in rural areas (Comilla: 1.50, Rangpur: 1.04) (Table 10). 


\section{PERCEPTION OF SON PREFERENCE}

\section{Gender preference among women, husband and mother-in-law}

Sex preference among women, husband and mother-in-law for second and third births is presented in Figure 2. Third births of women were chosen for analysis in conformity with the fertility rate of highfertility eastern regions of the country (TFR: 2.8 to 3.1). Expressed preference for sons and daughters is displayed while "No preference" is not shown.

The preference for baby's gender is contingent upon the sex of the living child and there is a strong desire for a gender-balanced composition of children. Although preferences about the sex of a child are contingent upon the sex composition of living children, the desire for gender-balance in children is stronger when couples have only daughters. For example, preference for a son as the second child was stronger among women and their husbands who had a girl as the first child (80-89\%) than the preference for daughter expressed by women and their husbands who had a boy as the first child (69-78\%). Couples hardly expressed desire to have two sons in consecutive births. For example, very few women and their husbands preferred to have boy as the second child even after having a boy as the first child, with no district-wise differences (6-7\%). Differences between districts in the preference for either boys or girls as the second child are negligible (Figure 2).

Figure 2: Gender preference among women, husband and mother-in-law for the second birth (in percent)

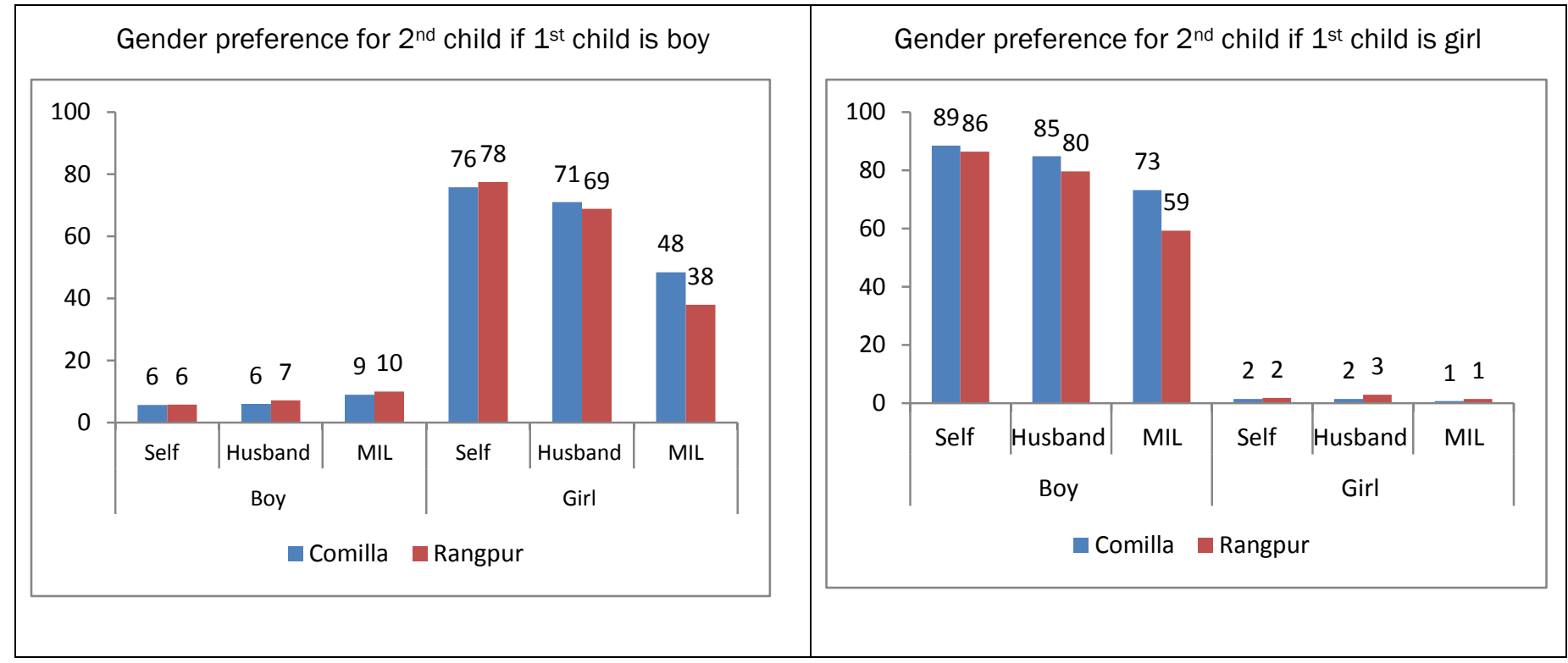

MIL= Mother-in-law 
Preference for the gender of third child is nearly similar to that of second child in direction, achieving mix-gender composition of children (Figure 3). Preference for son as the third child is almost universal among women and their husbands (90-99\%) who had two girls. While strong, a less intense preference for daughter as the third child was expressed by women and their husbands who had two boys (76-92\%). If women have had two boys, hardly any women along with their husbands and mothers-in-law preferred boy as the third child. Similarly, no women along with their husbands and mothers-in-laws preferred girl as the third child when having two girls. Though a preference for mixgendered composition of children is evident, it is stronger among couples having only daughters than among those having only sons.

Figure 3: Gender preference among women, husband and mother-in-law for the third birth (in percent)

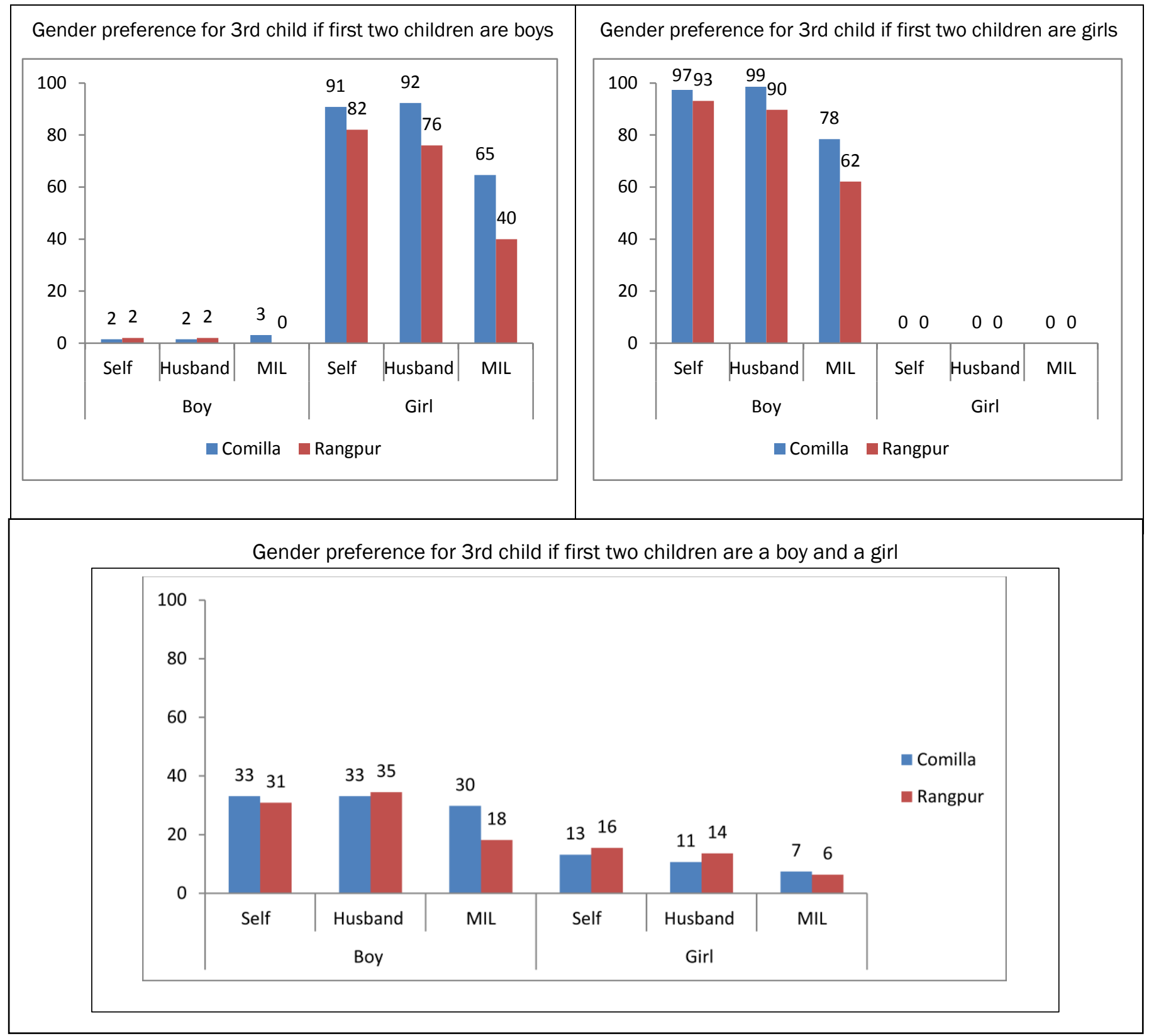


Even after having 2 children with balanced sex, women and husbands prefer boy over girl as the third child. The desire to have a girl as the third child is less intense compared with the preference for having a boy among those having one boy and one girl. For example, one-third of women and their husbands expressed a desire to have son as the third child while a lower proportion of women (11-16\%) desired to have daughter as the third child, after having one boy and one girl (Figure 3).

\section{Attitudes reflecting son preference}

Assessment of women's attitudes about having sons and daughters reveals that son preference was prevalent in both study districts (Table 11). Considerable proportions of women believed that a son is essential to continue the family line (81-88\%), that having a son determines a woman's status in her family (73-84\%), and that a family without a son gets less respect in society than other families (31$48 \%)$. While lower, considerable percentages of women also agreed that a woman with just daughters is unfortunate (11-28\%). Inter-district differences were not notable. Rangpur, the district with normal sex ratios, revealed a stronger son preference on three of the four indicators.

Table 11: Women reporting various attitudes relating to son preference (in percent)

\begin{tabular}{|c|c|c|c|c|c|c|}
\hline \multirow{2}{*}{ Son preference } & \multicolumn{2}{|c|}{ Urban } & \multicolumn{2}{|c|}{ Rural } & \multicolumn{2}{|c|}{ Total } \\
\hline & Comilla & Rangpur & Comilla & Rangpur & Comilla & Rangpur \\
\hline \multicolumn{7}{|l|}{ Women agreeing that: } \\
\hline $\begin{array}{l}\text { It is important to have sons } \\
\text { because they only can } \\
\text { continue the family line }\end{array}$ & 73.2 & $82.3 *$ & 88.8 & $94.2 *$ & 81.0 & $88.3 * * *$ \\
\hline $\begin{array}{l}\text { It is important to have sons } \\
\text { because having a son } \\
\text { determines a woman's } \\
\text { status }\end{array}$ & 71.2 & $79.6 *$ & 75.4 & $88.8 * * *$ & 73.3 & $84.2 * * *$ \\
\hline $\begin{array}{l}\text { If a family does not have a } \\
\text { son, it gets less respect in } \\
\text { society }\end{array}$ & 33.5 & 25.8 & 28.5 & $70.8 * * *$ & 30.9 & $48.3 * * *$ \\
\hline $\begin{array}{l}\text { A women with only daughters } \\
\text { is unfortunate }\end{array}$ & 18.3 & $10.0 * *$ & 38.1 & $11.9 * * *$ & 28.2 & $11.0 * * *$ \\
\hline Index of son preference (0-4) & 1.96 & 1.98 & 2.31 & $2.66 * * *$ & 2.14 & $2.32 * *$ \\
\hline Cronbach's alpha & 0.71 & 0.48 & 0.59 & 0.48 & 0.65 & 0.51 \\
\hline $\begin{array}{l}\text { Whether husband or in-laws } \\
\text { forced the respondent to } \\
\text { have a son }\end{array}$ & 4.3 & 3.5 & 5.0 & 3.8 & 4.6 & 3.7 \\
\hline $\mathrm{N}$ & 257 & 260 & 260 & 260 & 517 & 520 \\
\hline
\end{tabular}

* Significant at 0.05, ** Significant at 0.01, * ** Significant at 0.001 
An index was created that summed women's responses on these four indicators of son preference. Women reported attitudes reflecting son preference on an average of 1.96-2.66 of the four statements overall, with small district-wise differences. Attitudes reflecting son preference were more pronounced in rural than urban areas. Rural women from Rangpur were more likely than their urban counterparts to express a strong social preference for sons. The contrast of Comilla's higher sex ratio at birth with lower son preference is surprising and it is the higher level of education and improved economic condition of Comilla that is assumed to lead women to express less intense social preference for son.

Table 11 also reveals the extent to which son preference is imposed upon a married woman by her husband and/or mother-in-law. A negligible proportion of women admitted that the husband and mother-in-law coerced them to continue having children till a son is born (4-5\%), with no notable difference between districts.

\section{Attitudes reflecting girl value}

Table 12 describes the girl value which is reflected in the daughter's economic role in the family and daughter's rights to family property inheritance. An overwhelming majority of women agreed that a daughter can support her parents in their old age (Comilla: 78\%, Rangpur: 96\%) and a girl should inherit same amount of property as boys (Comilla: 80\%, Rangpur: 88\%). Women in Rangpur were considerably more likely than those in Comilla to attach more value to girls, suggestive of a culture of greater economic role of girls and women in Rangpur. It is the poor economic condition of Rangpur district that requires women to earn a livelihood along with men.

Table 12: Women reporting attitudes reflecting girl value (in percent)

\begin{tabular}{|c|c|c|c|c|c|c|}
\hline \multirow{2}{*}{ Reasons for valuing girls } & \multicolumn{2}{|c|}{ Urban } & \multicolumn{2}{|c|}{ Rural } & \multicolumn{2}{|c|}{ Total } \\
\hline & Comilla & Rangpur & Comilla & Rangpur & Comilla & Rangpur \\
\hline \multicolumn{7}{|l|}{ Women agreeing that: } \\
\hline $\begin{array}{l}\text { Daughter can support her } \\
\text { parents }\end{array}$ & 82.9 & $95.8 * * *$ & 72.3 & $95.8 * * *$ & 77.6 & $95.8 * * *$ \\
\hline $\begin{array}{l}\text { A girl should inherit same } \\
\text { amount of property as boys }\end{array}$ & 80.5 & $93.1 * * *$ & 79.6 & 82.3 & 80.1 & $87.7 * * *$ \\
\hline $\mathrm{N}$ & 257 & 260 & 260 & 260 & 517 & 520 \\
\hline
\end{tabular}

* Significant at 0.05, ** Significant at 0.01, * ** Significant at 0.001 


\section{Perspectives of service providers on son preference}

\section{Reasons for son preference}

Almost all key informants, irrespective of district, acknowledged the persistence of son preference. Analysis of perspectives of service providers on the presence of son preference in the country reveals social and economic dependency of a family on son-a key element of a patrilineal and patriarchal kinship system. Almost all key informants mentioned financial support for parents in old age and continuing family lineage as the main reasons for son preference, while some mentioned "keeping property within the family" as another reason. A few key informants referred to family anxiety for having a daughter. On the other hand, some mentioned the benefits of having son as it can bring dowry.

Son preference happens because of social, financial and religious reasons. The existing laws in our country allow nephews to inherit property partially if couples do not have a son. Daughters do not get the right of full ownership of all parental properties and moneys. Daughters are not the successors (who continue family lineage). That's why people prefer son. - Sonologist, age 49, male, Comilla.

Everyone craves for a son. Sons can work, they can earn while a daughter can earn too, but not like a son. Besides, daughter's income will go to her husband, not to her parents. Besides, sons are the successor of a family, not a daughter." - Mid-level provider, age 41, female, Comilla

In our society, women are not that valued. Abusing women is a common practice. Parents of a girl always have concerns about the future of their daughter in marital family. They fear that after marriage their daughter may be tortured by in-laws. If parents fail to give dowry, it will create problem in future. For these reasons, parents start to worry when a girl is born. - Mid-level provider, age 47, female, Comilla

\section{Weakening of son preference}

Key informants observed variations in the intensity of son preference among community members. While some mentioned a decline in son preference in their district, others mentioned an increase in such preference. Views of service providers, particularly doctors, indicate a weakening of son preference as a large proportion of them stated that people do not want son as before. In particular, young couples do not have the preference for a male child as mentioned by all the doctorrespondents, while less than half of the mid-level providers reported the same. A few key informants cited a presence of daughter preference as well.

People have son preference, but it is decreasing. Educated people do not have such preference. People who are less educated and do not have any financial support prefer son. I asked women who had 4-5 children the reasons for having many children. Almost all of them had daughters only and had many children in the hope of a son. - Doctor, age 52, male, Comilla

I think parents now-a-days do not have any preference. People are much more educated now. They are more aware. Long ago, people hoped their daughter-in-law would take care of them, so they wanted son. But now it is not the reality. Now-a-days, daughter takes care of parents, not daughter-inlaw. - Mid-level provider, age 57, female, Comilla 
Things are changing intensely. Women are now more independent and educated and prefer a healthy child instead of a son. -Mid-level provider, age 47, female, Comilla

Because of lack of education, people of our country are yet to develop the value that teaches them son and daughter are same and equal. But people are now more aware, they are beginning to understand that if they educate daughters, they can become son. - Mid-level provider, age 40, female, Comilla

Son preference is decreasing day by day. Only families, who have 3-4 daughters, are desperate for having a son. - Mid-level provider, age 41, female, Comilla

Things are changing. People do not prefer son as before. Earlier, people would distribute sweets when a son was born, but now people distribute sweets to celebrate the birth of a daughter. Now people realize that a daughter is better than a son in many ways. Daughters look after parents, earn for them and will live with parents as long as they let her. Even after her marriage daughters take care of parents as much as they can. Besides, people now-a-days do not want more than 2-3 children. People do not think much about the sex of their children. - Doctor, age 50, male, Comilla

Whenever I deliver a male child, couples spend a good amount of money as tips to hospital staff. Good thing is this kind of son preference is decreasing. People are more educated now. Young couples do not have son preference. - Obstetrician-Gynecologist, age 51, female, Rangpur

In response to the question on how people react when a son is born, many key informants pointed out higher contentment of the family members when son is born and special care for mother for delivering a son. Key informants also illustrated that birth of a son after several daughters brings joy to the family. For example:

...After delivery, a woman becomes very happy when we tell her that she gave birth to a son. Women become unhappy when they come to know that they gave birth to a daughter. We see such disappointment among women who give birth to a daughter if she already has one or two daughters. When a woman who already has a girl child, gives birth to a girl again, she suffers from depression after delivery and it becomes very hard to manage her. Most of the times they cry. - ObstetricianGynecologist, age 45, female, Comilla

Now-a-days, people are much more aware. They generally don't discriminate between son and daughter. Even so, birth of a son brings different level of happiness in a family. Husband and in-laws become more pleased with the woman. I know from experience of delivering babies, in-laws, husband and the woman herself become happier when a son is born. They bring sweets to celebrate. They do not become upset when it is a girl, but they are not as happy either. - Mid-level provider, age 52, female, Comilla

When a mother gives birth to a son, her importance in the family increases. On the other hand, when it is a girl, sometimes her husband and her mother-in-law inflict mental and physical pressure on her. - Mid-level provider, age 52, female, Rangpur

\section{Perspectives of program implementers on son preference}

\section{Reasons for son preference}

Social and economic reasons emerged as the main driver for son preference. Two-thirds of the program implementers mentioned shelter, economic support, last resort and family legacy as the reasons for son preference in the community. Inheritance of family property is another driver among people for preferring son (widely mentioned by respondents from Dhaka). An underlying reason for 
son preference is lack of education (as affirmed by 5 out of 12 respondents, mostly from Dhaka). The practice of dowry is hardly cited as the driver for son preference as only two program implementers considered dowry contributing to son preference.

For example:

Earlier, every family had 9-10 children. So the number of sons and daughters wasn't something people would think about. But this is the $21^{\text {st }}$ century. People want small family. Two children are enough for them. Among these two children, if both are boys, people think it's good. If one is a boy and the other is a girl, that's good too. But when both are girls, parents have regrets. Even if they don't say it, they want a boy ...I think, in every district of Bangladesh, people become overjoyed when a son is born. It really doesn't matter whether they have one or ten male children. This reaction is normal because when a woman has a son she feels secure. Financial support is not as important as security. I know from my working experience that a man, whether he is a son, a father, a husband, a brother or even a boyfriend, is like a security blanket. The safety and security individuals feel because of a male presence can be of different types. Parents think their son will look after them and support them in their old age. This is financial security. On the other hand, a sister thinks, even after her marriage, her brother will be concerned about her happiness, her well-being. If any trouble comes, he will be at her side. This is social security. - Program implementer, age 58, female, Comilla

In our country, parents become dependent on their children at their old age. And it's hard to depend on daughters since they go to husband's house after marriage. So naturally people want son to depend on. Another thing is, people need a son to keep their properties and money in their own family. It's hard for people to give away their hard-earned money and properties to someone outside the family. - Program implementer, age 58, female, Dhaka

\section{Weakening of son preference}

Of 12 program implementers, nine stated a weakening of son preference while only one respondent from Comilla mentioned an increase in son preference. Many key informants believed that the situation was changing, with young, urban and better-educated couples displaying no son preference. They noted that son preference among young couples is not as strong as among their parents and grandparents, which signals a gradual disappearance of traditional greater value of sons over daughters. Many cautioned, however, that change is slow, with rural and less educated families still preferring sons, and the older generation still pressuring the young to have a son.

\section{For example:}

Women always take extra care of male members of the family, be it son or husband. Women give their earnings to their husbands. But the situation is changing now. Women are more aware now-a-days and take care of themselves too...But in rural areas, women still give preference to their sons. In-laws do not take care of their daughter-in-law as highly as their son. So in rural areas, where light of education hasn't reached to expected level, women are not empowered and do not have financial independence, men receive extra care. In urban areas, people do not do these anymore. - Program implementer, female, age 58, Comilla

I think son preference varies from person to person. For example, I have three daughters. But my wife and I never felt we need a son. But my mother always pressured me for a son. In her eyes, a son is the future of a family. Our society is not that much developed yet. People still think, only son can lead a family. It will take more time to change people's mentality. They think son will earn for the family, so they need a son. - Program implementer, age 46, male, Comilla 
Key informants described the jubilation that surrounds the birth of a son. For example:

Son preference depends on many things. Everybody has their personal reasons for having such preference. Earlier, people reacted to the birth of a daughter. I have seen many bitter experiences about people's son preference. One time a parent left their own child at the hospital just because it was a girl. Another time, a man from a neighboring district came to me and said after eight years of trying, his wife gave birth to a son. He ordered $100 \mathrm{~kg}$ of sweets to celebrate this occasion. Even the boxes of sweets were custom made with his son's photo and name on top. - Program implementer, age 62, female, Dhaka

Key informants also described the grief that surrounds the birth of a daughter. For example,

I have seen people's disappointment with the birth of a daughter in my professional life. More than one time I have seen husband left his wife and newborn daughter at the hospital. Husband and inlaws don't want to pay hospital bills when they learn it's a girl. - Program implementer, age 58, female, Dhaka

\section{ATTITUDES TO SEX SELECTION}

Direct questions were posed to assess women's attitudes about the acceptability of abortion of female fetuses. Abortion of a female fetus if the family already has one or more daughters is hardly accepted by women. Despite the large proportions considering disclosure of the sex of the fetus acceptable, few women (0-2\%) justified the abortion of a female fetus. Notably, a few respondents (0-1\%) supported abortion of male fetus if the family already has sons, which is unexpected in the patriarchal society of Bangladesh. None from rural Rangpur supported abortion based on fetal sex.

Table 13: Attitude towards sex selection among women (in percent)

\begin{tabular}{lcccccc}
\hline & \multicolumn{2}{c}{ Urban } & \multicolumn{2}{c}{ Rural } & \multicolumn{2}{c}{ Total } \\
\cline { 2 - 7 } Attitude Indicator & Comilla & Rangpur & Comilla & Rangpur & Comilla & Rangpur \\
\hline $\begin{array}{l}\text { Abortion of a female fetus if } \\
\text { the family already has } \\
\text { daughter(s) }\end{array}$ & 1.9 & 0.4 & 1.2 & $0.0^{*}$ & 1.5 & $0.2^{*}$ \\
$\begin{array}{l}\text { Abortion of a male if the } \\
\text { family already has son(s) }\end{array}$ & 0.4 & 1.5 & 0.4 & 0.0 & 0.4 & 0.8 \\
$\begin{array}{l}\text { Better for women with two or } \\
\text { more daughters to have a test } \\
\text { and abort a female fetus than } \\
\text { bringing up many daughters }\end{array}$ & 0.8 & $4.2^{* *}$ & 0.4 & 0.4 & 0.6 & $2.3^{*}$ \\
$\mathbf{N}$ & 257 & 260 & 260 & 260 & 517 & 520 \\
\hline
\end{tabular}

* Significant at 0.05, ** Significant at 0.01, *** Significant at 0.001

Aborting female fetus for family with daughters at the expense of bringing up many daughters was hardly supported by women. A maximum of 4 percent of the respondents from urban Rangpur considered it better for women with two or more daughters to abort a female fetus than bringing up many daughters. Such attitude towards gender-biased sex selection remained negligible elsewhere (Table 13). 


\section{FERTILITY STOPPING BEHAVIOR}

\section{Use of contraception}

Use of any family planning methods by married women of reproductive age was higher in Comilla than in Rangpur. Findings presented in Table 14 suggest limited use of any contraception prior to the first birth. Women from Rangpur were less likely to use any family planning method before having their first child than those from Comilla (23\% vs. 29\%). In Rangpur there is a large difference between urban and rural women in using any family planning method, while such difference for Comilla is small.

Table 14: Use of contraception among women by order of births (in percent)

\begin{tabular}{|c|c|c|c|c|c|c|}
\hline \multirow{2}{*}{ Used any FP methods } & \multicolumn{2}{|c|}{ Urban } & \multicolumn{2}{|c|}{ Rural } & \multicolumn{2}{|c|}{ Total } \\
\hline & Comilla & Rangpur & Comilla & Rangpur & Comilla & Rangpur \\
\hline $\begin{array}{l}\text { Use of FP methods before } \\
\text { first birth }\end{array}$ & 31.5 & 32.7 & 26.5 & $12.3 * * *$ & 29.0 & $22.5^{*}$ \\
\hline $\mathrm{N}$ & 257 & 260 & 260 & 260 & 517 & 520 \\
\hline \multicolumn{7}{|l|}{$\begin{array}{l}\text { Use of FP methods before } \\
\text { second birth }\end{array}$} \\
\hline First child is a boy & 81.5 & 82.8 & 77.4 & 73.2 & 79.4 & 78.3 \\
\hline $\mathrm{N}$ & 124 & 128 & 124 & 112 & 248 & 240 \\
\hline First child is a girl & 84.2 & 82.6 & 72.1 & 62.8 & 78.1 & 72.1 \\
\hline $\mathrm{N}$ & 133 & 132 & 136 & 148 & 269 & 280 \\
\hline \multicolumn{7}{|l|}{$\begin{array}{l}\text { Use of FP methods before } \\
\text { third birth }\end{array}$} \\
\hline Two boys & 93.8 & 80.0 & 87.9 & 84.0 & 90.8 & 82.0 \\
\hline $\mathrm{N}$ & 32 & 25 & 33 & 25 & 65 & 50 \\
\hline $\begin{array}{l}\text { Two girls } \\
\mathbf{N}\end{array}$ & $\begin{array}{r}93.8 \\
32\end{array}$ & $\begin{array}{r}81.8 \\
22\end{array}$ & $\begin{array}{r}73.8 \\
42\end{array}$ & $\begin{array}{r}83.3 \\
36\end{array}$ & $\begin{array}{r}82.4 \\
74\end{array}$ & $\begin{array}{r}82.8 \\
58\end{array}$ \\
\hline $\begin{array}{l}\text { One boy one girl } \\
\mathrm{N}\end{array}$ & $\begin{array}{r}82.4 \\
51\end{array}$ & $\begin{array}{r}90.2 \\
41\end{array}$ & $\begin{array}{r}78.6 \\
70\end{array}$ & $\begin{array}{r}75.4 \\
69\end{array}$ & $\begin{array}{r}80.2 \\
121\end{array}$ & $\begin{array}{r}80.9 \\
110\end{array}$ \\
\hline
\end{tabular}

* Significant at $0.05, * *$ Significant at $0.01, * * *$ Significant at 0.001

Conversely, second and higher-order births were preceded by far greater use of contraception. Use of any family planning method jumped from less than 30 percent before a first birth to more than 72 percent before a second birth, and the third birth witnessed even higher use. Limited use of contraception before first birth and exceptionally higher use of contraception in second and following births indicate increasing intention of couples to avoid pregnancy, which is more pronounced in urban settings. Gender of preceding birth did not seem to have any impact on the use of family planning methods, except among women who had two sons. Nearly universal use of contraception before third child among women having two sons from Comilla indicates their stronger intention to avoid pregnancy. 


\section{Disclosure of fetal sex}

There is no law forbidding the disclosure of sex of the fetus in the country. Ultrasound is widely used by pregnant women from both districts to assess the development of the fetus, and to know the sex of the fetus. Women were asked whether they had undergone ultrasound during any of their pregnancies, and if so, whether information was obtained on the outcomes of the test, including fetal condition, fetal growth and fetal gender ${ }^{6}$. Findings are presented in Table 15.

Women from Comilla were more likely to have undergone ultrasound test than those of Rangpur: 79 percent versus 59 percent. Ultrasound is largely used for checking fetal health, that is, to check the position and growth of the fetus. In the process, most were informed about the sex of the fetus as well, in both districts. Even so, rural-urban differences were evident. The practice of obtaining information on fetal sex is lower among rural respondents compared with their urban counterparts. Women from rural Rangpur were least likely to use ultrasound to obtain information about sex of fetus (34 percent), implying women's limited access to ultrasound compared with other areas. Conversely, women from urban Comilla were most likely to have received information on the sex of the fetus through ultrasound (Table 15).

Table 15: Use of ultrasound to obtain information about sex of the fetus (in percent)

\begin{tabular}{|c|c|c|c|c|c|c|}
\hline \multirow{2}{*}{ Indicator } & \multicolumn{2}{|c|}{ Urban } & \multicolumn{2}{|c|}{ Rural } & \multicolumn{2}{|c|}{ Total } \\
\hline & Comilla & Rangpur & Comilla & Rangpur & Comilla & Rangpur \\
\hline $\begin{array}{l}\text { Had ultrasound test in any } \\
\text { pregnancies }\end{array}$ & 82.9 & 76.5 & 74.6 & $41.2 * * *$ & 78.7 & $58.8 * * *$ \\
\hline \multicolumn{7}{|l|}{ Outcomes of ultrasound test } \\
\hline Fetal condition & 79.4 & 75.4 & 71.9 & $41.2 * * *$ & 75.6 & $58.3 * * *$ \\
\hline Fetal growth & 80.9 & 75.4 & 73.8 & $41.2 * * *$ & 77.4 & $58.3 * * *$ \\
\hline Sex of fetus & 70.4 & 67.3 & 59.2 & $33.8 * * *$ & 64.8 & $50.6 * * *$ \\
\hline $\mathrm{N}$ & 257 & 260 & 260 & 260 & 517 & 520 \\
\hline
\end{tabular}

* Significant at 0.05, ** Significant at 0.01, *** Significant at 0.001

\footnotetext{
${ }^{6}$ Information of the use of ultrasound was also gathered anonymously, through a sealed envelope that contained a question about the respondent's experience of undergoing ultrasound to obtain information about sex of the fetus. Use of ultrasound for sex detection as reported anonymously lies between 24 and 55 percent, which is lower than levels reported through face-to-face interview (34 to 70 percent).
} 
Questions were also posed to women about whether a friend or relative had obtained information about the sex of the fetus, and whether they knew of someone in their community who had done so. As evident from Table 16, consistently more women reported knowing women in their village/mohalla who had received information about the sex of their fetus. In contrast, relatively few women reported awareness of a friend or relative who had obtained information about the sex of their fetus. Fewer women from rural Rangpur reported awareness of friends/relatives who had used ultrasound to know fetal sex; in contrast, almost twice as many women from rural Comilla reported acquaintance with a friend or relative who had done so (70\% vs. 30\%). Indeed, as many as 89 percent of women in rural Comilla knew someone in their community who had undergone ultrasound and had found out the sex of their fetus.

Table 16: Use of ultrasound to know sex of the fetus by relatives and other women in community (in percent)

\begin{tabular}{lllllll}
\hline \multirow{2}{*}{ Recipient } & \multicolumn{2}{c}{ Urban } & \multicolumn{2}{c}{ Rural } & \multicolumn{2}{c}{ Total } \\
\cline { 2 - 7 } & Comilla & Rangpur & Comilla & Rangpur & Comilla & Rangpur \\
\hline $\begin{array}{l}\text { Friends/relatives having } \\
\text { ultrasound to know sex of fetus }\end{array}$ & 56.0 & 62.3 & 69.6 & $30.0^{* * *}$ & 62.9 & $46.2^{* * *}$ \\
$\begin{array}{l}\text { Someone in community having } \\
\text { ultrasound to know sex of fetus }\end{array}$ & 81.3 & 79.2 & 89.2 & $70.4 * * *$ & 85.3 & $74.8^{* * *}$ \\
$\mathbf{N}$ & $\mathbf{2 5 7}$ & $\mathbf{2 6 0}$ & $\mathbf{2 6 0}$ & $\mathbf{2 6 0}$ & $\mathbf{5 1 7}$ & $\mathbf{5 2 0}$ \\
\hline
\end{tabular}

* Significant at $0.05, * *$ Significant at $0.01, * * *$ Significant at 0.001

\section{Practice of disclosure of the sex of the fetus by parity}

Use of ultrasound to know the sex of the fetus varies by the order of pregnancies and by regions. Women are more inclined to know the fetal sex in second and third births (31-48\%). On the other hand, information on the fetal sex was known to 23-34 percent of women pregnant with first child. Women in Comilla were more likely to report disclosure of the sex of the fetus than were those in Rangpur, and disclosure appeared to be contingent on the sex of the previous child. In Comilla, women at parity 2 whose first child was a daughter were more likely to have been informed about the sex of the second child than were those women whose first child was a son (49\% and $38 \%$ respectively). In Rangpur, the disclosure of the sex of the fetus among women at parity 2 was not clearly related to the sex of the previous child, as shown in the negligible difference in the use of ultrasound between groups of women having either son or daughter (34-37\%) (Table 17). 
Table 17: Percentages of women by experiences of personal disclosure of the sex of the fetus by parity and sex of previous child

\begin{tabular}{|c|c|c|c|c|c|c|}
\hline \multirow[t]{2}{*}{ Disclosure of fetal sex } & \multicolumn{2}{|c|}{ Urban } & \multicolumn{2}{|c|}{ Rural } & \multicolumn{2}{|c|}{ Total } \\
\hline & Comilla & Rangpur & Comilla & Rangpur & Comilla & Rangpur \\
\hline \multirow[t]{2}{*}{$1^{\text {st }}$ parity } & 44.0 & $34.6 *$ & 23.8 & $11.2 * * *$ & 33.8 & $22.9 * * *$ \\
\hline & (257) & $(260)$ & $(260)$ & (260) & (517) & (520) \\
\hline \multirow[t]{2}{*}{$2^{\text {nd }}$ parity } & 52.1 & 50.0 & 35.4 & $21.2 * * *$ & 43.7 & $35.6 * *$ \\
\hline & $(257)$ & $(260)$ & $(260)$ & (260) & (517) & (520) \\
\hline $1^{\text {st }}$ child -son & $\begin{array}{l}43.5 \\
(124)\end{array}$ & $\begin{array}{l}49.2 \\
(128)\end{array}$ & $\begin{array}{l}31.5 \\
(124)\end{array}$ & $\begin{array}{l}23.2 \\
(112)\end{array}$ & $\begin{array}{r}37.5 \\
(248)\end{array}$ & $\begin{array}{r}37.1 \\
(240)\end{array}$ \\
\hline $1^{\text {st }}$ child - daughter & $\begin{array}{l}60.2 \\
(133)\end{array}$ & $\begin{array}{l}50.8 \\
(132)\end{array}$ & $\begin{array}{l}39.0 \\
(136)\end{array}$ & $\begin{array}{l}19.6 * * * \\
(148)\end{array}$ & $\begin{array}{r}49.4 \\
(269)\end{array}$ & $\begin{array}{r}34.3 * * * \\
(280)\end{array}$ \\
\hline \multirow[t]{2}{*}{$3^{\text {rd }}$ parity } & 52.2 & 45.5 & 44.1 & $20.8 * * *$ & 47.7 & 30.7 \\
\hline & (115) & $(88)$ & (145) & (130) & (260) & (218) \\
\hline $2^{\text {nd }}$ child - son & $\begin{array}{l}54.5 \\
(55)\end{array}$ & $\begin{array}{l}43.2 \\
(44)\end{array}$ & $\begin{array}{l}50.0 \\
(66)\end{array}$ & $\begin{array}{l}19.4 * * * \\
(62)\end{array}$ & $\begin{array}{r}52.1 \\
(121)\end{array}$ & $\begin{array}{r}29.2 * \star * \\
(106)\end{array}$ \\
\hline $2^{\text {nd }}$ child - daughter & $\begin{array}{l}50.0 \\
(60)\end{array}$ & $\begin{array}{l}47.7 \\
(44)\end{array}$ & $\begin{array}{l}39.2 \\
(79)\end{array}$ & $\begin{array}{l}22.1^{*} \\
(68)\end{array}$ & $\begin{array}{r}43.9 \\
(139)\end{array}$ & $\begin{array}{r}32.1 \\
(112)\end{array}$ \\
\hline
\end{tabular}

* Significant at $0.05, * *$ Significant at $0.01, * * *$ Significant at 0.001

\section{Pregnancy termination and sex selection}

Eight percent or fewer women had experienced pregnancy termination. The practice of pregnancy termination differs by district and rural-urban residence, with a higher incidence for Rangpur than Comilla, and among urban than rural women (Table 18). While the proportion of women who had ever experienced pregnancy termination was similar in the rural areas of both districts (4\%), it was higher in urban Rangpur than urban Comilla: 12 percent versus 8 percent.

Pregnancy termination typically took place within the first trimester in all settings, conforming to the Menstrual Regulation (MR) Law in Bangladesh in which MR is permitted up to a gestation period of 10 weeks. Nearly all urban respondents had their pregnancies terminated within three months of gestation while all rural respondents from Rangpur reported the same. A few pregnancy terminations took place at four months of pregnancy and beyond, and the figures do not differ much across districts.

Reasons for undergoing pregnancy termination rarely included sex selection. Caution is needed in interpreting these findings since the analysis is based on an extremely small eligible sample. Most abortion-seekers terminated pregnancies as part of their family building strategy. Nearly all the pregnancies that had been terminated were conducted for fertility limiting reasons, that is, for limiting or spacing family size, because the last child was too young or because of contraceptive failure. 
Mostly, pregnancies were mistimed: two-thirds of those reporting pregnancy terminations did not want another child at that time. Unwanted pregnancy (did not want the child at all) is another major reason for pregnancy termination (16 percent). Refusal of husband to have another child was reported by 10 percent of women in Comilla, while it is nearly three folds in Rangpur at 28 percent. Contraceptive failure was more likely to be reported by women from Comilla than Rangpur (16\% versus 7\%). Findings also suggest that no women in Comilla, and just one woman from Rangpur reported that she had undergone abortion because the fetus was female (Table 18).

Table 18: Pregnancy termination and its reasons women (in percent)

\begin{tabular}{|c|c|c|c|c|c|c|}
\hline \multirow{2}{*}{ Indicator } & \multicolumn{2}{|c|}{ Urban } & \multicolumn{2}{|c|}{ Rural } & \multicolumn{2}{|c|}{ Total } \\
\hline & Comilla & Rangpur & Comilla & Rangpur & Comilla & Rangpur \\
\hline $\begin{array}{l}\text { Ever had any induced } \\
\text { abortion/MR }\end{array}$ & 7.8 & 12.3 & 4.2 & 4.2 & 6.0 & 8.3 \\
\hline \multicolumn{7}{|l|}{$\begin{array}{l}\text { Months of pregnancy at } \\
\text { termination* }\end{array}$} \\
\hline$<3$ months & 7.4 & 11.2 & 3.1 & 4.2 & 5.2 & 7.7 \\
\hline 4 months and above & 0.8 & 1.2 & 1.2 & 0.0 & 1.0 & 0.6 \\
\hline$N$ & 257 & 260 & 260 & 260 & 517 & 520 \\
\hline \multicolumn{7}{|l|}{$\begin{array}{l}\text { Reasons for pregnancy } \\
\text { termination } * *\end{array}$} \\
\hline $\begin{array}{l}\text { Last child was too } \\
\text { young/ Didn't want } \\
\text { another child at that } \\
\text { time }\end{array}$ & 45.0 & 65.6 & 81.8 & 72.7 & 58.1 & 67.4 \\
\hline $\begin{array}{l}\text { Didn't want another child } \\
\text { at all }\end{array}$ & 25.0 & 15.6 & 0.0 & 18.2 & 16.1 & 16.3 \\
\hline Husband did not want & 10.0 & 28.1 & 9.1 & 27.3 & 9.7 & 27.9 \\
\hline Was too young/old & 5.0 & 6.3 & - & - & 3.2 & 4.7 \\
\hline Contraceptive failure & 25.0 & 6.3 & 0.0 & 9.1 & 16.1 & 7.0 \\
\hline Fetus was female & 0.0 & 3.1 & - & - & 0.0 & 2.3 \\
\hline Doctor advised & 5.0 & 3.1 & 9.1 & 0.0 & 6.5 & 2.3 \\
\hline Others $* * *$ & 10.0 & 12.5 & 18.2 & 9.1 & 12.9 & 11.6 \\
\hline $\mathrm{N}$ & 20 & 32 & 11 & 11 & 31 & 43 \\
\hline
\end{tabular}

* A few women had multiple episodes of pregnancy termination

** Multiple responses

$* * *$ Others include: Financial, job problem, weakness 


\section{INITIATIVES TO ENHANCE THE STATUS OF FEMALES}

\section{A. Impact of gender-focused programs}

\section{EXPOSURE TO CCT AND MICROCREDIT PROGRAMS}

Bangladesh has a long history of conditional cash transfer (CCT) programs to encourage secondary education of girls; girls studying in high school are entitled to receive a stipend, and almost all women were aware of this program. Respondents who had a daughter eligible for such a stipend at the time of survey were asked whether their daughters had received a stipend. Nearly 90 percent of women from Rangpur reported their daughter had received a secondary school scholarship, compared to 73 percent from Comilla. No other CCTs are available for girls in Bangladesh.

Table 19: Exposure to CCT and microcredit program (in percent)

\begin{tabular}{lrrrrrr}
\hline \multirow{2}{*}{ Indicator } & \multicolumn{2}{c}{ Urban } & \multicolumn{2}{c}{ Rural } & \multicolumn{2}{c}{ Total } \\
\cline { 2 - 7 } & Comilla & Rangpur & Comilla & Rangpur & Comilla & Rangpur \\
\hline $\begin{array}{l}\text { Knows that girls studying in } \\
\text { high school are entitled to } \\
\text { receive stipend }\end{array}$ & 99.2 & $93.8 * *$ & 97.3 & 93.8 & 98.3 & $93.8^{* * *}$ \\
N & 257 & 260 & 260 & 260 & 517 & 520 \\
$\quad \begin{array}{l}\text { Daughters received } \\
\text { stipend/scholarshipt }\end{array}$ & 72.7 & 85.7 & 73.7 & 92.9 & 73.2 & 89.3 \\
N & 22 & 14 & 19 & 14 & 41 & 28 \\
\hline $\begin{array}{l}\text { Awareness of micro-credit } \\
\text { program }\end{array}$ & 97.3 & $99.6 *$ & 100.0 & 98.8 & 98.6 & 99.2 \\
$\quad$ Ever received micro-credit & 35.0 & $60.4 * * *$ & 50.4 & $40.8 *$ & 42.7 & $50.6 *$ \\
N & 257 & 260 & 260 & 260 & 517 & 520 \\
\hline
\end{tabular}

* Significant at 0.05, ** Significant at 0.01, *** Significant at 0.001

$\dagger$ Based on responses of women who had a daughter eligible for stipend at the time of survey

Microfinance provides self-employment to millions of female entrepreneurs in Bangladesh.

Expansion of micro-credit programs has been a major contributor to the transition to commercialization of women's work from subsistence economic activities and/or unpaid household works. As shown in Table 19, awareness of microfinance is universal in Bangladesh. Women's participation in microfinance is moderate, with some variation between districts (Comilla: $43 \%$, Rangpur: 51\%). The number of beneficiaries of microcredit was lowest for urban Comilla (35\%). 


\section{PROGRAM IMPLEMENTERS' PERSPECTIVES}

The study sought the perspectives of program implementers (both national- and district-level) regarding the impact of the female school stipend program, female employment in the apparel industry, and women's access to microcredit on improving the situation of girls and young women in the community. Program implementers agreed that these schemes were well-known at community level, and that many girls and young women had taken advantage of them.

The stipend program provides a cash incentive and tuition subsidy to each girl attending a secondary school who satisfies three eligibility criteria: (i) attend 75 percent of school days; (ii) attain a minimum level of measured academic proficiency ( 45 percent marks at the examination); and (iii) remain unmarried.

Key informants agreed that girls were more likely to remain in school because of the conditional cash transfer program, that is, the stipend program, and suggested that the female secondary education stipend program had resulted in more girls completing a secondary education. The stipend program appears to have created a positive attitude among community members towards delaying age at marriage for girls, conforming to one of the key conditions for receiving cash stipend. For example:

...Secondary school stipend program brought a very positive change in our society. Before this program, girls went to primary schools only and after that wait 2-3 years at their house until they get married. But now, they spend 2-3 years at secondary school and learn as much as they can. Attending secondary level education has certain effect on girls. They are more grown up at this stage, so they remember what they learn. - Program implementer, age 45, female, Dhaka

Program implementers were not convinced, however, that the importance of daughters or the desire for a daughter had increased because of such program. A few program implementers considered the program useful in changing attitudes about girls; but no informants believed that the stipend program had brought changes in the demand for sons or daughters or that it would play a role in deterring women from undergoing sex-selection tests and subsequent abortion of a female fetus. For example:

Programs for girls' education definitely have an impact on people. Presence of girls in the schools is much higher now than boys. Women have reached a new level in the society. Things are changing rapidly. People are much more aware now. It is not sure whether these changes are impacting son preference. I think empowerment of girls will help reduce son preference to a point, but it is not possible to erase son preference completely. - Program implementer, age 46, male, Comilla

Secondary stipend program has brought a very positive change in our society. Because of secondary stipend, parents send their daughters to schools much more than before. But it has not stopped early marriage. Lack of social security and the demand of young girls at the marriage market are the main reasons behind early marriage. But people's mentality is changing. They value their daughters more. Still, they prefer son, but do not despair having a daughter either. - Program implementer, age 38, female, Rangpur 
Usefulness of the stipend program in deterring women from undergoing sex-selection tests and subsequent abortion of girl fetus was not perceived by the implementers.

Program implementers were generally positive about the impact of microcredit and of female employment in apparel industry on son preference. They acknowledged the effect of working in the apparel industry on the autonomy of young women and in raising the value and importance of daughters in the family, and changing parents' views about the ability of daughters to support their parents economically. One national-level program implementer highlighted the growing independence of girls working in ready-made garment (RMG) factories:

...Girls who work in RMG factories are independent in most cases. Their families generally do not display a preference for sons. Daughters who work in garment factories support their parents. Yet, parents don't like the fact that working in a garment factory means that a girl lives in the city, away from her family, and away from the protection and control of her parents. Also, it's difficult for parents to marry off girls who work in the apparel industry. - Program implementer, age 45, female, Dhaka

The impact of microcredit on son preference is not as large as that of apparel industry. Yet, the majority of program implementers suggested a relationship between access to microcredit and the increased importance of daughters in the family. At the same time, they acknowledged that it did not have a strong impact on son preference. For example:

...Microcredit does not have any impact on son preference. Taking microcredit alone does not make one empowered. Some women are involved in productive activities with their husbands and use microcredit. In most cases, women act a medium to bring the loan home. Their husbands use it for business or other purposes. - Program implementer, age 45, female, Dhaka

In short, key informants maintained that entitlements for girls, notably the secondary school stipend program, as well as employment opportunities for young women and microcredit facilities for women, may change parents' perceptions about the value of daughters, but may not affect their desire for a male child. 


\section{B. Impact of advocacy and community mobilization}

\section{WOMEN'S EXPOSURE TO ADVOCACY AND COMMUNITY MOBILIZATION}

A number of programs have been undertaken in Bangladesh to reduce the strong preference for sons, including advocacy to reduce discrimination against the girl child. Questions were posed to women that assessed whether they had been exposed to advertisements about non-discrimination against girl child, and whether exposed to messages by a religious leader, health worker or NGO worker.

Exposure to advocacy efforts related to non-discrimination against daughters varied widely across districts. Greater exposure to advocacy efforts was reported for Comilla than Rangpur. Women from Comilla were four times more likely than those from Rangpur to report exposure to advertisements, and differences were almost equally wide in both urban and rural settings (67\% vs. $18 \%, 61 \%$ vs. 14\%). Almost all those exposed to such messages reported the mass media (TV/radio/newspaper) as primary source of such information (Table 20).

In contrast, hardly any respondent (less than $2 \%$ ) had been exposed to any message about genderbiased sex selection or termination of pregnancies carrying a female fetus; this is not surprising given earlier findings about the limited prevalence of gender-biased sex selection and subsequent abortion of female fetus. Health center and women's club were key sources for such information among women who reported having heard anything that discourages sex determination and abortion of female child (not shown in the table). Hardly any advocacy efforts in the country are aimed at discouraging sex determination and abortion of female fetus.

Comparison of the role of community leaders (religious leaders, health workers, and NGO workers) in advocating equal treatment between daughters and sons indicates greater social interaction in Comilla than in Rangpur. Women from Comilla were significantly more likely than those from Rangpur to report exposure to messages by community leaders advocating equal treatment of daughters and sons. More women were exposed to such messages delivered by religious leaders and health care providers than by NGO workers. Regarding the role of religious leaders in raising the value of girls, differences between districts are remarkable. A maximum of 49 percent of the women from rural Comilla cited the role of religious leaders in raising the value of girl child in their community. The proportion of the respondents mentioning the role of health workers in raising the value of girls did not exceed 25 percent with no remarkable difference across study districts. The extent of NGO advocacy activities was clearly limited in the study districts (Table 20). 
Table 20: Exposure to advocacy and community mobilization (in percent)

\begin{tabular}{|c|c|c|c|c|c|c|}
\hline \multirow{2}{*}{ Advocacy activities } & \multicolumn{2}{|c|}{ Urban } & \multicolumn{2}{|c|}{ Rural } & \multicolumn{2}{|c|}{ Total } \\
\hline & Comilla & Rangpur & Comilla & Rangpur & Comilla & Rangpur \\
\hline $\begin{array}{l}\text { Saw advertisement to } \\
\text { eliminate discrimination } \\
\text { against girl child }\end{array}$ & 66.9 & $17.7 * * *$ & 61.2 & $14.2 * * *$ & 64.0 & $16.0 * * *$ \\
\hline \multicolumn{7}{|l|}{ Source of advertisement $\dagger$} \\
\hline TV/radio/newspaper & 66.9 & $17.7 * * *$ & 60.0 & $14.2 * * *$ & 63.4 & $16.0 * * *$ \\
\hline Health center & 1.2 & 0.0 & 1.2 & 0.0 & 1.2 & 0.0 \\
\hline $\begin{array}{l}\text { Heard anything that } \\
\text { discourages sex } \\
\text { determination and abortion } \\
\text { of female child }\end{array}$ & 1.9 & 1.9 & 2.3 & $0.0 *$ & 2.1 & 1.0 \\
\hline \multicolumn{7}{|l|}{ Community mobilization } \\
\hline $\begin{array}{l}\text { Religious leader ever } \\
\text { talked about treating } \\
\text { daughters and sons alike } \\
\text { or saving the girl child }\end{array}$ & 37.7 & $16.5 * * *$ & 48.8 & $8.1 * * *$ & 43.3 & $12.3 * * *$ \\
\hline $\begin{array}{l}\text { Health worker ever talked } \\
\text { about treating daughters } \\
\text { and sons alike or saving } \\
\text { the girl child }\end{array}$ & 23.7 & 25.4 & 19.2 & 11.8 & $21.5^{*}$ & $18.1 *$ \\
\hline $\begin{array}{l}\text { NGO ever talked about } \\
\text { treating daughters and } \\
\text { sons alike or saving the girl } \\
\text { child }\end{array}$ & 5.4 & 6.5 & 15.0 & $3.1 * * *$ & 10.3 & $4.8 * *$ \\
\hline $\mathrm{N}$ & 257 & 260 & 260 & 260 & 517 & 520 \\
\hline $\begin{array}{l}\text { * Significant at } 0.05, * * \text { Signific } \\
\text { † Multiple responses }\end{array}$ & $1, * *$ & cant at $\mathrm{C}$ & & & & \\
\hline
\end{tabular}

\section{WOMEN'S AWARENESS OF LAWS ON ABORTION AND SEX SELECTION}

Although there is a well-defined law on abortion in Bangladesh, lack of awareness of the abortion law was universal in study settings, ranging from 0-2 percent. Indeed, only 1 out of 1,037 respondents mentioned correctly the legitimacy of pregnancy termination within 10 weeks of gestation. Given that there is no law in the country that prohibits gender-biased sex selection, it is not surprising that not a single respondent was aware of legislation related to sex selection (not shown in the table).

The majority of the respondents did not perceive the necessity for laws to prevent sex selection. Views concerning the need to formulate laws were mixed: 39 percent of women from Comilla and 13 percent of those from Rangpur perceived the need for laws to prevent gender-biased sex selection (Table 21). 
Table 21: Perception among women on the necessity of law for prohibiting sex selection (in percent)

\begin{tabular}{|c|c|c|c|c|c|c|}
\hline \multirow{2}{*}{ Indicator } & \multicolumn{2}{|l|}{ Urban } & \multicolumn{2}{|l|}{ Rural } & \multicolumn{2}{|l|}{ Total } \\
\hline & Comilla & Rangpur & Comilla & Rangpur & Comilla & Rangpur \\
\hline $\begin{array}{l}\text { Perceived the necessity for } \\
\text { laws to prevent sex } \\
\text { selection }\end{array}$ & 38.5 & $16.5 * * *$ & 39.2 & $8.8 * * *$ & 38.9 & $12.7 * * *$ \\
\hline$N$ & 257 & 260 & 260 & 260 & 517 & 520 \\
\hline \multicolumn{7}{|l|}{$\begin{array}{l}\text { Justifying need for law on } \\
\text { sex selection }\end{array}$} \\
\hline $\begin{array}{l}\text { Sex selection prevention } \\
\text { law should ensure a girl- } \\
\text { child rights to live }\end{array}$ & 92.9 & 100.0 & 84.3 & $100.0 *$ & 88.6 & $100.0 * *$ \\
\hline $\begin{array}{l}\text { Sex selection prevention } \\
\text { law is needed otherwise } \\
\text { there will be shortage of } \\
\text { bride }\end{array}$ & 75.8 & $95.3 * *$ & 82.4 & 91.3 & 79.1 & $93.9 * *$ \\
\hline $\mathrm{N}$ & 99 & 43 & 102 & 23 & 201 & 66 \\
\hline
\end{tabular}

* Significant at $0.05, * *$ Significant at $0.01, * * *$ Significant at 0.001

Women who perceived the need for law on sex selection were requested to express their views on the reasons justifying formulation of such law. There was widespread support for the need for laws that ensure a girl child's right to live, although fewer women in Comilla (89\%) than Rangpur (100\%) so reported. Likewise, more women in Rangpur than Comilla reported the need for a law to ensure the natural availability of brides for the next generation (94\% versus $79 \%$ ) (Table 21 ).

\section{PERSPECTIVES OF SERVICE PROVIDERS ON DISCLOSURE OF FETAL SEX AND SEX SELECTION}

\section{Disclosure of fetal sex}

Key informants agreed that disclosure of the sex of the fetus was widespread, that pregnant women regularly sought disclosure, and most service providers informed their clients about the sex of the fetus. Key informants also speculated that more than half of the service providers give information about sex of the fetus upon requests from clients. It is the providers at private facilities and diagnostic centers and sonologists who are more likely to reveal sex of the fetus more often than other providers.

In a few instances, key informants mentioned that when pregnant women and family members want to know sex of the fetus, service providers usually discourage them from doing so. Instead, they give counseling on how to take care of the mother and emphasize that such information was not important for child-birth. When families insist even after counseling, service providers advise them 
for ultrasonogram. A program implementer from Dhaka city who is a radiologist illustrated an example on the degree of client's interest to know information on fetal sex:

Actually people do ultasonogram to know the sex of the fetus. Service providers, who do not disclose the sex of the fetus, loose clients. Once, a couple came to me for an ultrasonogram. When I did not disclose the sex of the fetus, the couple became very upset. And they went to another clinic and had the ultrasonogram performed there, and got information about the sex of the fetus. - Radiologist, age 36, male, Dhaka

A radiologist from Rangpur related how he manages the request for information on fetal sex:

When a client comes for ultrasonogram, we ask her about the sex of her first child. If she tells her first born is a girl, and if we see she is going to have a girl again, then we don't tell her about the sex of the fetus. We say it's not clear if it's a boy or a girl. - Radiologist, age 34, male, Rangpur

...People really don't think much about the sex of the fetus when it comes to their first child. But during the second pregnancy, women go through ultrasonogram. Even people in the rural areas know about this. When people find out they are not going to get a son, they become upset. But they do not undergo abortion. Not usually. In fact, urban people who are rich and educated are more likely to have an abortion. They do it to keep their family small, not because of the sex of the child. - Program implementer, age 58, female, Comilla

\section{Abortion of girl fetus}

Healthcare providers were probed about the extent to which abortion beyond 10 weeks took place in their district, and the extent to which sex selection was the motive for abortion. All key informants were aware of the law surrounding abortion in Bangladesh. About half of the key informants noted that violation of the abortion law does occur. Indeed, they estimated that up to 20 percent of pregnancy terminations occurring in study districts were illegal, that is, conducted among women who were more than 10 weeks pregnant. Even so, providers from both districts were unanimous in their conviction that the practice of sex-selective abortion was extremely rare. From two study districts, a few service providers mentioned that a negligible proportion of the abortions occurring in the study districts was sex selective. For example:

...There was an incident... I heard about an abortion of a 5-month-old girl fetus. A pregnant woman whose fetus was nearly five months old came to me to know the sex of the fetus. She came to me with an ultrasonogram report to know what the report said, whether it was a boy or a girl. I knew her, so I told her it's a girl fetus. Later, I heard that she went through an abortion. She came to me again later to discuss the matter. - Radiologist, age 49, male, Comilla

Similarly, program implementers stated that the practice of sex-selective abortion was extremely rare, but a few of them hinted at their potential occurrence. For example,

Sex selective abortion is very rare in our country. Financially, physically, socially, and morally-from every aspect it is not acceptable to the people of rural areas in the country. Besides, our technology is not that developed yet. - Program implementer, age 33, male, Rangpur

... If there was available technology in our country to know the sex of the fetus within 10 weeks of pregnancy, the number of sex-selective abortion would be increased. - Program implementer, age 62, male, Dhaka 
Even though many people get upset when they learn they are going to have daughter, they do not go through abortion. Sex-selective abortion is very uncommon in our country. And this is because we lack technology and the process is costly. - Program implementer, age 38, female, Rangpur

\section{Enforcement of abortion law}

Quantitative findings indicate that nearly all pregnancy terminations took place within 10 weeks of gestation (without knowing the fetal sex), which is legal under the MR policy. The qualitative component of the study attempted to explore the extent to which the abortion law is enforced for pregnancy termination after 10 weeks of gestation.

\section{PERSPECTIVES OF SERVICE PROVIDERS ON ABORTION}

All respondents reported their ignorance of how effectively abortion law is enforced. It has emerged from the discussion that abortion service is easily available despite the presence of a restrictive law, and abortion is often performed violating the law of gestation. Ignorance of the breach of the law for gestation age is common among respondents from Rangpur. None of the respondents knew whether the law was enforced following the occurrence of sex-selective abortion.

There was no district-based monitoring system for illegal abortion. None of the respondents could mention presence of any structured system that monitors illegal abortion in their respective district.

Half of the respondents had no idea whether service providers are punished for illegal abortion. Only three out of 32 respondents (all from Comilla district) reported witnessing a case where the service provider was punished for criminal abortion. Revocation of license for abortion is completely unknown to key informants. Respondents were not cognizant of any cases or complaints ever lodged against sex-selective abortion in the district.

No specific program is in place to raise awareness about sex-selective abortion among service providers. Questions regarding the operation, coverage and impact of abortion-awareness programs were mostly unanswered. Only four key informants specifically mentioned that government's family planning department and NGO run abortion-awareness programs. 


\section{DISCUSSIONS AND RECOMMENDATIONS}

Bangladesh is characterised by an east-west divide in sex ratios at birth. While the western region shows normal sex ratios at birth, the eastern region displays distorted sex ratios. To understand the factors that contribute to regional variations in the sex ratio at birth, a household survey was conducted among married women aged 18-49 years who had at least two living children, the youngest of whom was aged 0-5. Views of healthcare providers on gender-biased sex selection and of program implementers on the impact of gender-focused programs on the importance of having a daughter in the family were also gathered. The study was located in Comilla district from the eastern region which had an adverse sex ratio at birth and Rangpur district from the western region having a normal sex ratio.

Caution should be exercised in interpreting the findings from our survey, as the size of the sample of women interviewed (1,037 respondents) was not adequate to reach a definitive conclusion. Future studies are needed that work with a larger sample, so that findings on differentials across characteristics can be generalized.

\section{Factors affecting sex ratios at birth}

Findings have highlighted that the preconditions for skewing of sex ratios prevail: the small-family norm is widespread, gender norms continue to be hierarchical and son preference exists, particularly in rural areas; and pre-natal diagnostic techniques are used by large proportions of women to both assess the development of the fetus and know the sex of the fetus. This section discusses the extent to which low fertility, access to sex-selection technology and preference for sons have affected differences in the sex ratio at birth in these two contrasting districts of Bangladesh.

\section{LOW FERTILITY AND STOPPING BEHAVIOR}

Women in both districts had on average 2.5-2.7 living children. Women in Rangpur were more likely than those in Comilla to have just two children (66\% vs. 55\%); in contrast, they were less likely than those from Comilla to have three children (23\% vs. $34 \%)$. High-parity women and their husbands do not seem to be content to have only sons or only daughters, and a strong preference for children of both sexes is evident. The distribution of women mentioning two-child ideal shows a strong desire for one boy and one girl in both study sites-women from Rangpur almost unanimously expressed the preference for one boy and one girl while such preference is slightly lower in Comilla (Rangpur:97\%, Comilla: 89\%).

Even so, son preference was evident in both districts, which is stronger in Comilla than Rangpur. The intention to have an additional childr was, for example, clearly related to the sex of living children among women in Comilla. Indeed, there was some suggestion that women from Comilla with more sons than daughters were more likely than those from Rangpur to report wanting no more children (50\%, 32\% respectively). This indicates the presence of son preference in Comilla despite the desire for a small family growing stronger. Correspondingly, women from Comilla with more daughters than sons were less likely than those in Rangpur to report wanting no more children (Comilla 32\%, 
Rangpur: 47\%), suggestive of lack of contentment with the current composition of children. Furthermore, in Comilla, the desire for gender-balance in the number of children was stronger when couples have only daughters. For example, preference for a son as the third child is almost universal among women and their husbands who had two girls (women: $97 \%$, husbands: 99\%) while a slightly less, yet intense preference for daughters as the third child was expressed by women and their husbands who had two boys (women: $91 \%$, husbands: $92 \%$ ).

Women in Comilla were more likely to report disclosure of the sex of the fetus than were those in Rangpur, and disclosure appeared to be contingent on the sex of the previous child. In Comilla, women at parity 2 whose first child was a daughter were more likely to have been informed about the sex of the second child than were those women whose first child was a son. Associations were modest in Rangpur.

Findings suggest an increase in the use of contraception with parity, from a low use of contraception before first birth (23-29\%) to markedly higher use of contraception in second (72-79\%) and following births. Use of contraception to stop childbearing in second and higher-order births is notably higher in Comilla which implies that women from Comilla have stronger intention to avoid pregnancy at higher-order births.

Clearly, women's use of contraception was associated with the sex composition of their living children 7 . In Comilla, those with two sons were 50 percent more likely to have been practicing contraception than those with two daughters while in Rangpur, they were 17 percent more likely to have done so. Differences were particularly pronounced in rural areas (Comilla: 1.50, Rangpur: 1.04). These findings suggest women from Comilla were more likely to base their childbearing strategies on the number of sons they had than were those from Rangpur.

\section{DISCLOSURE OF FETAL SEX AND SEX SELECTION}

Disclosure of the sex of the fetus was widespread in Bangladesh where it is not legally restricted. The practice of knowing the fetal sex is higher among women in Comilla in which sex ratios were distorted than in Rangpur having normal sex ratio (65\% vs. 51\%) and lower among rural women than among urban women. Despite large proportions of women considering disclosure of the sex of the fetus acceptable, hardly any women favored the termination of a female fetus (less than $2 \%$ ). Findings highlight, moreover, that termination of pregnancies carrying a female fetus was almost entirely absent as revealed from both the household survey and discussions with key informants. Indeed, the study found only one case of gender-biased sex selection in its survey of 1,037 women. Instead of sex selection, women undergo pregnancy termination as a means of fertility control offered as a part of family planning services. While 8 percent of women reported an abortion, almost all these abortions took place in the first trimester of pregnancy, when detection of the sex of the fetus is not possible through ultrasonography, and nearly all abortion-seekers terminated pregnancies for fertility-limiting reasons.

\footnotetext{
7 The extent to which women's use of contraception was associated with the sex composition of their living children is used as an indirect way of measuring the influence of son preference on the family planning behavior of couples. A simple indicator was constructed which measures the ratio of the proportion of women with two sons currently using contraception with the proportion of women with two daughters using contraception.
} 
This study suggests no discernible differences between women in the two districts in terms of sexselective abortion (which is nearly absent in both districts), however there is a suggestion that women in Comilla were more likely than those in Rangpur to continue childbearing till they had a son, and less likely to stop childbearing at low parities, irrespective of the composition of their children. In Rangpur, a normal sex ratio coexisted with higher rates of pregnancy termination as a means of ensuring small family size, and without seeking disclosure of the sex of the fetus, as part of family building strategy.

\section{PERCEPTION ON SON PREFERENCE}

Perception of sex preference among women indicates an increase in preferences for both son and daughter with increasing birth order, as women continue to have children until they achieve their desired composition of children. Demographic preference of son by parity indicates no notable difference across districts while it was stronger in rural than in urban setting.

Encouragingly, Rangpur exhibited a culture of attaching greater value on girls. Women in Rangpur were considerably more likely than those in Comilla to believe that a daughter can support her parents in their old age and a girl should inherit same amount of property as a boy, suggestive of a culture of greater autonomy for girls and women in Rangpur than in Comilla. It is worth noting that this district is credited for large contribution of female labor force to apparel industry and small industries, and greater financial reliance of parents on working daughters.

Surprisingly, attitudes reflecting son preference were more pronounced among rural women from Rangpur, which is not consistent with its lower sex ratio at birth. It is perhaps the lower education level and poor economic condition of rural Rangpur that are assumed to lead women to express more intense preference for son.

\section{Gender-focused initiatives to improve status of females}

\section{EXPOSURE TO FINANCIAL OPPORTUNITIES}

Conditional cash transfer programs for secondary school girls are implemented in Bangladesh. Use of school stipend program is higher in Rangpur than in Comilla. Views of program implementers (both national and district) regarding the impact of female school stipend program on improving the situation of girls were mixed. For example, the stipend program was observed to have played some role in delaying age at marriage for girls, conforming to one of the key conditions for receiving cash stipend. Only a few implementers considered the program useful in changing attitudes about girls; and not a single program implementer believed that the stipend program has brought changes in the demand for son/daughter.

Microfinance provides self-employment to millions of female entrepreneurs in Bangladesh. In Bangladesh, more women from the district with normal than distorted sex ratios reported accessing microcredit programmes (51\% versus $43 \%$ ). Access to micro-credit was perceived to have reduced discrimination against women and changed perceptions about the importance of daughters. 
Likewise, girls' access to the apparel industry was perceived to have increased importance of daughter in the family in Rangpur, which is strongly believed by program implementers. This means daughters are valued more than previously among poor families as female garment-workers provide some income support for their parents. A relatively wealthier condition of Comilla was reflected in its limited use of financial opportunities for females. While key informants from both districts agreed that the schemes could be successful in changing perceptions of daughters as liabilities and burdens, they were skeptical about the ability of the programs to change parents' preferences for sons over daughters.

\section{EXPOSURE TO ADVOCACY AND COMMUNITY MOBILIZATION}

Findings suggest that programs relating specifically to promoting awareness against gender-biased sex selection (or termination of pregnancies carrying a female fetus) do not exist in the country. Exposure to advocacy and community mobilization programs related, rather, to non-discrimination against daughters took place in both Rangpur and Comilla. It was women in Comilla who were more likely than those in Rangpur to have been exposed to these programs. Almost all those exposed to such messages reported the mass media (TV/radio/newspaper) as the primary source of such information. More women from Comilla than Rangpur were likely to be exposed to messages about equal treatment of daughters and sons delivered by religious leaders and healthcare providers. The extent of NGO advocacy activities was clearly limited in the study districts.

Exposure to advocacy and community mobilization efforts on promoting equal treatment of daughters and sons is limited in Rangpur. This finding suggests perhaps that programs relating to non-discrimination against daughters were more likely to focus on districts displaying high levels of discrimination than other districts.

\section{LEGAL INITIATIVES TO REDUCE SEX SELECTION}

Lack of awareness on the abortion law among women was universal in study sites. There is no law in the country that prohibits gender-biased sex selection. Findings suggest that women did not typically perceive a need for a law to prevent gender-biased sex selection; even so, more women in Comilla than Rangpur perceived this need (39\% versus 13\%).

Abortion is often performed violating the law of gestation (which is legally restricted beyond 10 weeks) and abortion laws were inadequately enforced. Key informants from both study districts suggested that abortions beyond ten weeks of gestation did take place, and that there was no system whereby abortions were monitored at the district level. Whether the law was enforced after illegal abortion had taken place is not known to most key informants. Perceptions of key informants concurred with reports of women that sex-selective abortions are extremely rare. Key informants also noted an absence of programs to raise awareness about gender-biased sex selection among service providers. 


\section{Way forward}

Women in both study districts exhibited a strong preference for a two-child family. The practice of disclosing the sex of the fetus is widespread in both study districts but the practice of sex-selective abortion was almost entirely absent, and women strongly opposed gender-biased pregnancy termination. Despite these similarities, findings suggest a stronger desire for a male child in Comilla than Rangpur. Sex of living children had an effect on the desire of women for more children and on the use of contraception. Women in Rangpur, in contrast, adhered more strongly to the small family norm, irrespective of the composition of their children. Given that access to second trimester abortions is not as difficult to obtain as the violation of the law related to terminating pregnancies beyond prescribed gestation period is barely punished, potential does exist, particularly in Comilla, for resort to the termination of pregnancies carrying a female fetus. Overall, the findings are inconclusive and mixed. There is a need for further research covering several other pockets that have distorted sex ratios at birth.

Women in the district with adverse sex ratios (Comilla) was as likely as or more likely than their counterparts in the district with normal sex ratios (Rangpur) to have been exposed to awareness raising, advocacy and community mobilization activities intended to promote equal treatment of daughters and sons. There is no program that advocates gender-biased sex selection.

Several recommendations emerge from this study having relevance for efforts to ensure a balanced sex ratio at birth. Indeed, given that gender-biased sex selection is not a serious concern at present, measures are needed that challenge gender norms and strongly held preferences for sons over daughters:

- Expand programs intended to enhance the autonomy of women and girls: It is critical to enhance the autonomy of women and girls, by increasing opportunities for subsidized education for girls and for paid employment for women; our findings have suggested that perceptions about the value of girls can change when communities observe girls providing economic support to parents substituting economic role of sons.

- Provide safety nets to protect poor rural women: At the same time, safety net programs for poor rural women can be a useful instrument for reducing son preference, since poverty remains a key driver for son preference in the rural setting. Such programs will not only provide much-needed support to poor women in the short term, but may also change attitudes about reliance of sons for old-age support in the longer term.

- Guideline needed to prohibit the use of technology for sex detection. Potential exists for misuse of disclosure of the sex of the fetus; therefore, a clearly defined service protocol on using the technology for sex detection is needed.

- Strengthen advocacy and community mobilization efforts intended to challenge gender norms: It is essential that outreach and other programs are implemented that attempt to break down traditional norms about sons versus daughters, while at the same time, focusing on parents to promote equal opportunities for daughters and sons, and enhance awareness about and encourage parents to access available programs and entitlements for their daughters. 


\section{REFERENCES}

Asadullah, M.N., N. Chaudhury. 2006. "Conditional cash transfer and educational gender gaps: Insights from Bangladeshi households." Available at: http://paa2007.princeton.edu/papers/70330.

Bangladesh Bureau of Statistics (BBS). 2011. Report on Labor Force Survey 2010. Dhaka: BBS, Ministry of Planning, Government of Bangladesh.

Gipson, J.D., M.J. Hindin. 2008. "Having another child would be a life or death situation for her: Understanding pregnancy termination among couples in rural Bangladesh," American Journal of Public Health, 98(10): 1821832. doi:10.2105/AJPH.2007.129262.

Guilmoto, C.Z. 2009."The sex ratio transition in Asia." Population and Development Review, 35(3): 519549.

Huq, L., N. Kabeer, S. Mahmud. 2012. “Diverging stories of son preference in South Asia: A comparison of India and Bangladesh." Working Paper No. 07. Dhaka, Bangladesh: BRAC Development Institute, BRAC University, Bangladesh.

Islam, M.S., S. Dogra. 2011. “Women empowerment in Bangladesh: The rise of the other half." ISAS Working Paper No. 119. Singapore: Institute of South Asian Studies, National University of Singapore. Available at: http://www.isas.nus.edu.sg/PublicationByCategory.aspx.

KFW. 2006. Bangladesh Gender Profile. Discussion Paper 42. Available at: https://www.kfw-entwicklungsbank.de/migration/Entwicklungsbank-Startseite/ Entwicklungsfinanzierung/Themen/Gender/L\%C3\%A4nderprofil-Bangladesch.pdf.

Khandker, S.R., M.M. Pitt, N. Fuwa. 2003. “Subsidy to promote girls' secondary education: The Female Stipend Program in Bangladesh." Available at: http://www.h.chiba-u.jp/mkt/revised\%20 fssap\%20paper9b.pdf.

National Institute of Population Research and Training (NIPORT), Mitra and Associates, ICF International. 2015. Bangladesh Demographic and Health Survey 2014 - Key Indicators. Dhaka, Bangladesh and Rockville, Maryland, USA: NIPORT, Mitra and Associates, and ICF International.

Saha, U.R., R. Bairagi. 2007. "Inconsistencies in the relationship between contraceptive use and fertility in Bangladesh." International Family Planning Perspectives, 33(1): 31-37.

Talukder, M.N., U. Rob, and F.R. Noor. 2014. “Assessment of Interventions on Sex Selection in Bangladesh." Dhaka: Population Council.

UN. 2013. World Population Prospects: The 2012 Revision. New York: Population Division, United Nations (UN). Available at: http://esa.un.org/unpd/wpp/index.htm.

UNICEF. 2011. "A perspective on gender equality in Bangladesh: From young girl to adolescent: What is lost in transition?" Dhaka: UNICEF Bangladesh. Available at: http://www.unicef.org/bangladesh/Gender paper Final 2011.pdf.

Vlassoff, M., A. Hossain, I. Maddow-Zimet, S. Singh, H.U. Bhuiyan. 2012. "Menstrual regulation and postabortion care in Bangladesh: Factors associated with access to and quality of services." New York: Guttmacher Institute. Available at: http://www.guttmacher.org/pubs/Bangladesh-MR.pdf. 